\title{
Permafrost in Svalbard: a review of research history, climatic background and engineering challenges
}

\author{
Ole Humlum, Arne Instanes \& Johan Ludvig Sollid
}

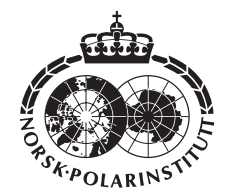

This paper reviews permafrost in High Arctic Svalbard, including past and current research, climatic background, how permafrost is affected by climatic change, typical permafrost landforms and how changes in Svalbard permafrost may impact natural and human systems. Information on active layer dynamics, permafrost and ground ice characteristics and selected periglacial features is summarized from the recent literature and from unpublished data by the authors. Permafrost thickness ranges from less than $100 \mathrm{~m}$ near the coasts to more than $500 \mathrm{~m}$ in the highlands. Ground ice is present as rock glaciers, as ice-cored moraines, buried glacial ice, and in pingos and ice wedges in major valleys. Engineering problems of thaw-settlement and frost-heave are described, and the implications for road design and construction in Svalbard permafrost areas are discussed.

O. Humlum, Dept. of Physical Geography, Institute of Geosciences, University of Oslo, Box 1042 Blindern, NO-0316 Oslo, Norway, and Dept. of Geology, University Centre in Svalbard, NO-9170 Longyearbyen, Norway,ole.humlum@geo.uio.no; A. Instanes, Instanes Consulting Engineers, Storetveitveien 96, NO-5072 Bergen, Norway; J. L. Sollid, Dept. of Physical Geography, Institute of Geosciences, University of Oslo, Box 1042 Blindern, NO-0316 Oslo, Norway.

Recent changes in the Arctic atmosphere-iceocean system have sparked intense discussions as to whether these changes represent episodic events or long-term shifts in the Arctic environment. Concerns about future climate change stem from the increasing concentration of greenhouse gases in the atmosphere. During the last 15 years the Arctic has gained a prominent role in the scientific debate regarding global climatic change (Houghton et al. 2001). Existing knowledge on Quaternary climate and Global Climate Models predicts that the effect of any present and future global climatic change would be amplified in the polar regions due to feedbacks in which variations in the extent of glaciers, snow, sea ice, permafrost and atmospheric greenhouse gases play key roles. Recent subcontinental-scale analysis of meteorological data obtained during the observational period lends empirical support to the alleged high climatic sensitivity of the Arctic (Giorgi 2002). Recently, however, Polyakov, Akasofu et al. (2002) and Polyakov, Alekseev et al. (2002) presented updated observational trends and variations of Arctic climate and sea ice cover during the 20th century which do not support the modelled polar amplification of temperature changes observed by surface stations at lower latitudes.

There is reason, therefore, to evaluate climate dynamics and their respective impacts on high latitude ecosystems, including permafrost regions. The latter currently occupies $20-25 \%$ of the land surface of the Northern Hemisphere (Péwé 1983; Zhang et al. 2000). Slight changes in mean annual air temperature, wind speed and precipitation have the potential to change the state of large regions of currently frozen ground (Nelson et al. 2001, 2002; Anisimov et al. 2002). 


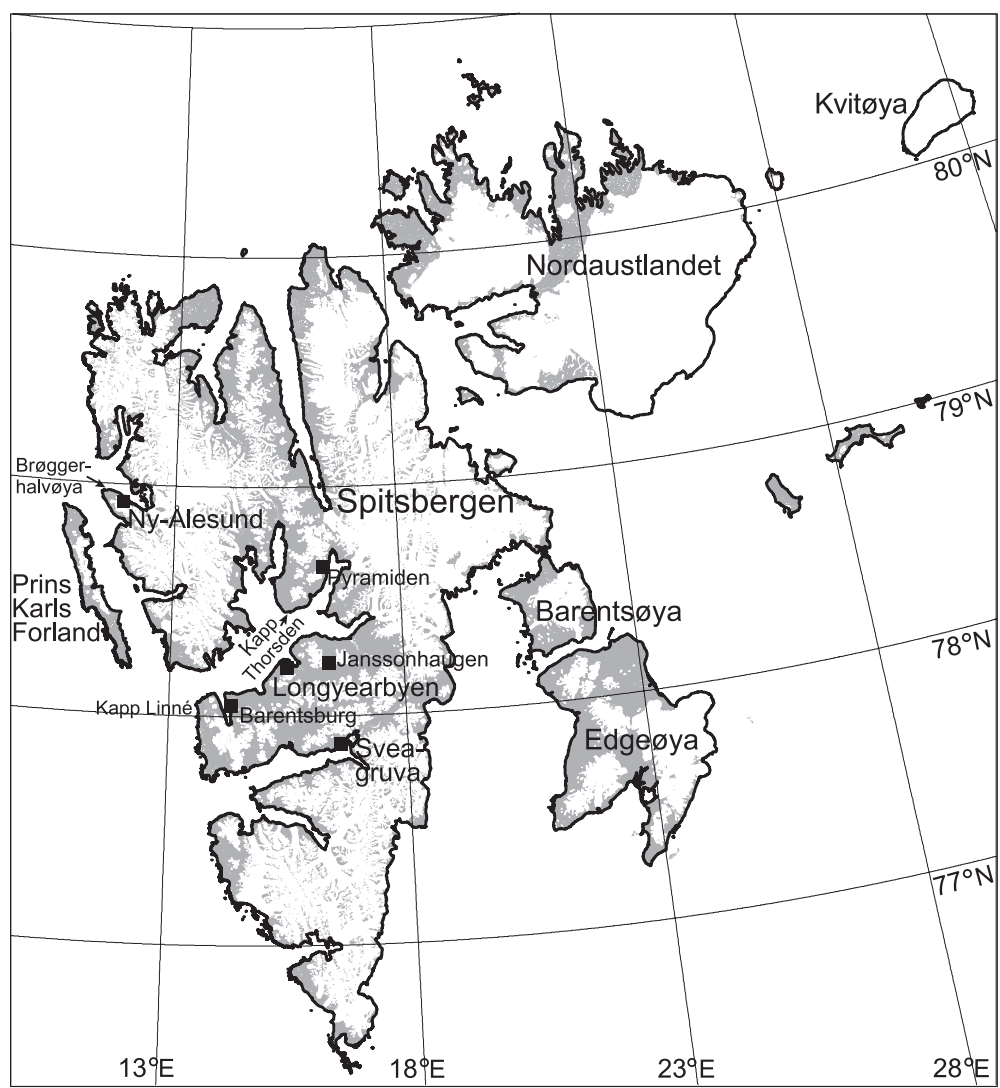

Fig. 1. Map of the Svalbard archipelago (small, southern island of Bjørnøya not shown), showing the position of places referred to in the text. Grey indicates permafrost areas (ca. $25000 \mathrm{~km}^{2}$ ) without ice cover.

\section{Svalbard permafrost research}

This section outlines research on permafrost in Svalbard, an archipelago of $63000 \mathrm{~km}^{2}$ (Fig 1), since the late 19th century. This example of an early international research effort was, especially during the first years, dominated by Nordic researchers. Some of the publications referred to below are published in Norwegian or other Nordic languages only. As such, they are not always easily accessible to an international audience. The research focus has traditionally been on the main island, Spitsbergen. Among many fine scientists, one in particular stands out: Olav Liestøl (1916-2002), who provided ideas and inspiration for many Nordic permafrost scientists active in Svalbard.

Permafrost was known to be present in Svalbard at least since the First International Polar Year in 1882 and the first coal mining operations in 1898. Ekholm (1890) measured ground temperatures at different depths below the terrain surface at Kapp Thordsen in 1883 . He was able to demonstrate temperature variations to a depth of $2 \mathrm{~m}$. Later, Holmsen (1913) studied ground ice in Colesdalen, central Spitsbergen. Observing ground ice at several sites below the upper marine limit, he was probably the first to demonstrate a late Holocene age for permafrost and ground ice at low altitudes in Svalbard.

Werenskiold (1922) published the first review of frozen ground phenomena in Spitsbergen. Other early observations relating to Svalbard permafrost were carried out by Huxley \& Odell (1924), Gripp (1926), Elton (1922, 1927) and Kulling (1937). From measurements of firn temperatures in the accumulation area of Fjortende Julibreen, Sverdrup (1935) was presumably one of the first to demonstrate that bedrock below large glaciers in Svalbard does not necessary need to be frozen. Orvin (1941) published descriptions of horizontal layers of ground ice (presumably refrozen ground water) from Spitsbergen. Later, Orvin (1944) addressed the apparent paradox of explaining permanent springs in a region with extensive per- 
ennial frozen ground.

Liestøl (1962) described so-called "talus terraces" from various sites in Svalbard. These rock-glacier-like features were described as consisting of recurrent layers of ground ice and debris, exposed to permafrost creep. Jahn (1960, 1965, 1967) described slope evolution, patterned ground, solifluction, rock falls and avalanches, including the June 1953 avalanche disaster in Longyearbyen. Jahn (1976) and Larsson (1982) both described another catastrophic mass movement event that affected Longyearbyen during a heavy rainstorm in August 1972. This event was due to saturation of unconsolidated near-surface sediments (the active layer) by heavy rain.

Liestøl (1976) was the first systematically to consider the thickness and thermal conditions of Svalbard permafrost. This classic paper describes the distribution of pingos, springs and permafrost in Spitsbergen. From observations made during mining operations, he was able to estimate the magnitude of the geothermal gradient - about $2-2.5^{\circ} \mathrm{C} / 100 \mathrm{~m}$ in central Spitsbergen. Péwé (1979) and Péwé et al. (1981) also discussed Svalbard permafrost in relation to climate and ongoing mining operations.

Several other papers merit identification in this review. For example, Liestøl (1976, 1980, 1986) measured permafrost temperatures and permafrost thickness in several deep boreholes on Spitsbergen, while Gregersen \& Eidsmoen (1988) studied near-shore permafrost conditions at Longyearbyen and Svea. Salvigsen \& Elgersma (1985) and Salvigsen et al. (1983) discussed the issue of taliks and karst features in permafrost in relation to large glaciers, major lakes or warm groundwater springs. Lauritzen \& Bottrell (1994) described microbiological activity in some of these Svalbard springs. Finally, Landvik et al. (1988) discussed the possible occurrence of submarine permafrost on the shelf around Svalbard from a glacial-isostatic point of view.

The Norwegian Committee on Permafrost established the first site for Arctic engineering research purposes in June 1978, at Svea (Bakkehøi 1982; Bakkehøi \& Bandis 1987, 1988). There, ground temperatures down to $8 \mathrm{~m}$ below a tundra surface and ground temperatures down to $2 \mathrm{~m}$ below an artificial concrete surface have since been collected. Further engineering aspects of permafrost in Svalbard are discussed by Gregersen (1988), Instanes (1988) and Orheim (1988). Sub- and intra-permafrost hydrologi- cal aspects have also been addressed by several workers, especially in relation to water supply at the Large-scale Research Facility in Ny-Ålesund, north-west Spitsbergen (e.g. Lauritzen 1991; Sandsbråten 1995; Haldorsen et al. 1996; Booij et al. 1998; Haldorsen \& Heim 1999).

The vertical temperature profile of thick permafrost has recently been recognized as an important means of obtaining information on past surface temperatures. This is the object of a joint European research initiative, Permafrost and Climate in Europe (PACE), that has established a number of permafrost monitoring sites in a north-south European transect (Sollid et al. 2000; Isaksen et al. 2001; Isaksen, Humlum \& Sollid 2003). The northernmost site is located on Janssonhaugen, in upper Adventdalen, central Spitsbergen. The temperature profile from the more than $100 \mathrm{~m}$ deep borehole clearly demonstrates the effect of a marked 20th century warming around 1920 as well as later meteorological variations (Isaksen, Ødegård et al. 2000; Isaksen, Vonder Mühll et al. 2000; Isaksen 2001; Isaksen, Humlum, Sollid et al. 2003).

Pingos are well-known phenomena in Svalbard. Svensson (1971) gave the first detailed description, based upon observations made in Adventdalen, near Longyearbyen. It was possible to obtain a maximum age for pingo initiation of about 2650 yr BP, suggesting a late Holocene age for permafrost near sea level in the region. The distribution and formation of pingos in Svalbard was further described and discussed in a seminal paper by Liestøl (1976). Yoshikawa \& Harada (1995) present additional observations on the rate and timing of pingo growth in central Spitsbergen. Salvigsen (1977) and Åkerman $(1982,1987)$ discuss the sporadic occurrence of palsas in Svalbard.

Ice wedges represent another typical example of geomorphic permafrost phenomenon present in Svalbard (Svensson 1976). They have been the object of intermittent research, often in association with other activities. Detailed studies on ice wedge dynamics have been carried out in Adventdalen by Matsuoka (1999), who monitored thermal cracking, and by Jeppesen (2001), who excavated a number of ice wedges to study their structure and to obtain material for ${ }^{14} \mathrm{C}$ dating and for oxygen isotope analyses. Recently, Christiansen (2003) has initiated a detailed monitoring scheme on air and ground temperatures, and automatic photographic registration of active ice 
wedges. Dating of organic material found in ice wedges (Jeppesen 2001) indicates that ice wedges near sea level have been initiated before about $2900 \mathrm{yr}$ BP; this lends support to the dating of adjacent pingo initiation by Svensson (1971). Presumably, therefore, permafrost near sea level in central Spitsbergen is a late Holocene phenomenon in Svalbard (Humlum 2003).

Rock weathering is usually thought to be enhanced in permafrost areas when compared to non-permafrost areas, and a variety of publications on Svalbard talus morphology, avalanches, rock glaciers, debris flows, paraglacial slope processes and other processes and landforms have appeared (e.g. Rapp 1960; Liestøl 1962; Åkerman 1980, 1984; Sollid \& Sørbel 1988a, 1992; André 1990, 1994, 1997; Berthling et al. 1998; Berthling et al. 2000; Isaksen, Ødergård et al. 2000; Isaksen, Vonder Mühll et al. 2000; Isaksen 2001; Korsgaard 2002; Mercier 2002). Ødegård \& Sollid (1993) and Ødegård et al. (1995) have investigated near-surface spring temperatures in a coastal rock cliff near Ny-Ålesund and the possible implications for bedrock weathering in this special permafrost environment. Detailed investigations on meteorological parameters and bedrock weathering rates have been carried out since 2001 in the near surroundings of Longyearbyen, by Prick (2003, in press).

Rock glaciers have been a research topic of great interest. Liestøl (1962) gave the first description of what are now known as rock glaciers, linking their formation to slope processes. The 1970s, 1980s and early 1990s saw several other investigations on the morphology of Svalbard rock glaciers (Chandler 1973; Swett et al. 1980; Humlum 1981; Lindner \& Marks 1985; Dzierzek \& Nitychoruk 1987), as well as their geophysical characteristics (Hoelzle 1993; Vonder Mühll 1996; Wagner 1996; Isaksen, Ødegård et al. 2000; Kääb et al. 2002; Ødegård et al. 2003a, 2003b).

The glacier-permafrost relation and its consequences for glacial sedimentology, hydrology and geomorphic activity have been investigated by Hambrey (1984), Liestøl (1986), Sollid \& Sørbel (1988b), Ødegård et al. (1992); Van der Wateren (1992), Lehmann (1993), Sollid et al. (1994), Vatne et al. (1995), Etzelmüller et al. (1996) and Boulton et al. (1999), while the relation between permafrost, supraglacial debris cover and the formation of debris-covered glaciers has been studied by Korsgaard (2002). The coupling between climate change, permafrost and glacial sedi- mentology and dynamics has been the object of separate investigations (e.g. Hamilton \& Dowdeswell 1996; Glasser \& Hambrey 2001). Murray et al. (2000) working at Bakaninbreen, southern Svalbard, especially stress the importance of permafrost for understanding surge-type glacier dynamics. Etzelmüller (2000) and Etzelmüller et al. (2000) studied surface changes in recently deglaciated permafrost terrain in four areas of Svalbard by comparing digital elevation models derived from aerial photographs. His study shows that thermo-erosion in deglaciated terrain is an important process, and that the average annual material mobilization due to thermo-erosion can be of the same order of magnitude as field-measured total annual suspended sediment transfer out of the catchments. Large ice-cored moraines are found in association with many glaciers in Svalbard today; these may also be considered a permafrost-related landform. Melting of their ice cores by river erosion or climate change results in slope instability and variations in the sediment transport of rivers draining these areas $(\mathrm{O}$. Liestøl, pers. comm. 1988).

Holmsen (1913) and Orvin (1941) provided some of the first observations on active layer thickness from Svalbard. Systematic monitoring of the active layer has been carried out in the vicinity of Kapp Linné since 1972 (Christiansen et al. 2003) and at Calypsostranda (south-central Spitsbergen) since 1986 (Repelewska-Pekalowa 1988; Christiansen et al. 2003). The active layer monitoring at Kapp Linné is the longest record in the world. Active layer monitoring has also been carried out at Janssonhaugen since 1998, at Longyearbyen since 2000 and at $\mathrm{Ny}$-Ålesund since 2001 (Brown et al. 2000; Christiansen et al. 2003; Isaksen, Humlum, Sollid et al. 2003). Meteorological and other local controls on active layer depths in Spitsbergen have recently been the focus of detailed research (Putkonen 1998; Oht 2002, 2003). Roth \& Boike (2001) investigated the dynamics of active layer temperatures from a mineral hummock field at Bayelva, on the Brøggerhalvøya peninsula, with special reference to conductive heat flux, generation of heat from phase transitions, and migration of water vapour. Active layer groundwater sampling has demonstrated that the principal means of solute acquisition for such water is the weathering of highly reactive active layer sediments by supra-permafrost groundwater (Cooper et al. 2002).

Recently, an interesting illustration of active 
layer thickness variations in Svalbard became apparent. The "Spanish Flu" killed over 40 million people worldwide in 1918. Seven men died of the disease in Longyearbyen that year and were interred in the local graveyard. Ground Penetrating Radar (GPR) was used to locate the seven coffins near the existing seven grave markers (Davis et al. 2000). The GPR indicated that the ground was disturbed to $2 \mathrm{~m}$ depth and was perennially frozen below $1 \mathrm{~m}$. Subsequent excavation showed that the tops of the coffins were buried less than $1 \mathrm{~m}$ deep, and that the modern active layer where the coffins were located was $1.2 \mathrm{~m}$ deep. Thus, the victims were only partly in permafrost, but virological and bacteriological investigations on recovered tissues were possible and provided an opportunity to isolate and identify the microorganisms involved in the 1918 influenza.

\section{Svalbard climate and permafrost}

Weather in the Arctic is characterized by "semipermanent" patterns of high and low pressure (Serreze et al. 1993; Serreze et al. 1995; Serreze $\&$ Barry 1998). These patterns are semipermanent because they appear in charts of long-term average surface pressure. They can be considered largely to represent the statistical signature where transitory high and low pressure systems that appear on synoptic charts tend to be most common. This pattern is relatively weakly developed in summer, but stronger in winter.

A major control, especially for winter weather and permafrost in the Svalbard region, is the Siberian High, an intense, cold anticyclone that forms over eastern Siberia in winter. Prevailing from late November to early March, it is associated with frequent cold air outbreaks over East Asia, and strong cooling in this region results in the lowest air temperatures in the Northern Hemisphere. During very cold winters the Siberian High extends to the west, covering Russia and parts of Europe. Airflow over the Nordic seas then is strong and southerly, causing advection of warm air to the Svalbard region, heavy snowfalls and quite often also periods of snowmelt even in the middle of winter. Conversely, when cold polar air masses extend over Svalbard, northern Europe is usually exposed to strong westerly airflow and heavy precipitation. Therefore, a thermal "seasaw" between northern Europe and Svalbard is often registered during winter.
In winter periods with calm conditions, the weather in the Svalbard valleys is dominated by shallow inversions where warm air overlies colder air near the terrain surface, decoupling surface winds from stronger upper layer winds. For this reason, surface wind speeds tend to be lower in winter than one might expect and cold (and dense) air tends to accumulate in topographic lows. In summer and autumn, inversions are less frequent and weaker, and the movement of low pressure systems (cyclones) across Svalbard dominate the weather.

Special climatic interest is often attached to the Svalbard region because this part of the Arctic apparently displays a unique climatic sensitivity. This was recognized early by both Ahlmann (1953) and Lamb (1977). Significant climatic variations in the Svalbard region during the 20th century have been well documented by meteorological data since 1911 (Førland et al. 1997). For example, a marked warming around 1920 within 5 years changed the mean annual air temperature at sea level from about $-9{ }^{\circ} \mathrm{C}$ to $-4{ }^{\circ} \mathrm{C}$ (Fig. 2). This is possibly the most pronounced increase in surface air temperature documented anywhere on the planet during the observational period. Later, from 1957 to 1968 , the air temperature sharply dropped by about $5{ }^{\circ} \mathrm{C}$, with a subsequent more gradual increase towards the end of the 20th century. In the latest Intergovnernmental Panel on Climate Change report (Houghton et al. 2001), attention is specifically drawn to the extraordinary high climatic sensitivity of Svalbard. This probably derives from three mechanisms. First, the islands are located directly in the main transport pathway for air masses into the Arctic Basin (Dickson et al. 2000). Second, Svalbard is located near the confluence of air masses and ocean currents with very different temperature characteristics, and large-scale meteorological phenomena such as the Siberian High may especially influence winter temperature conditions. Finally, the sensitivity is further enhanced by rapid variations in the sea ice extent, coupled with both atmospheric and oceanic circulation (Humlum 2002; Shapiro et al. 2003).

At the beginning of the 21st century, the mean annual air temperature (MAAT) is about $-5^{\circ} \mathrm{C}$ close to sea level in central Spitsbergen, while the mean annual precipitation is around $180 \mathrm{~mm}$ w.e. The $-10^{\circ} \mathrm{C}$ MAAT isotherm is presently located at about $700 \mathrm{~m}$ a.s.l., according to unpublished meteorological measurements since 2000 


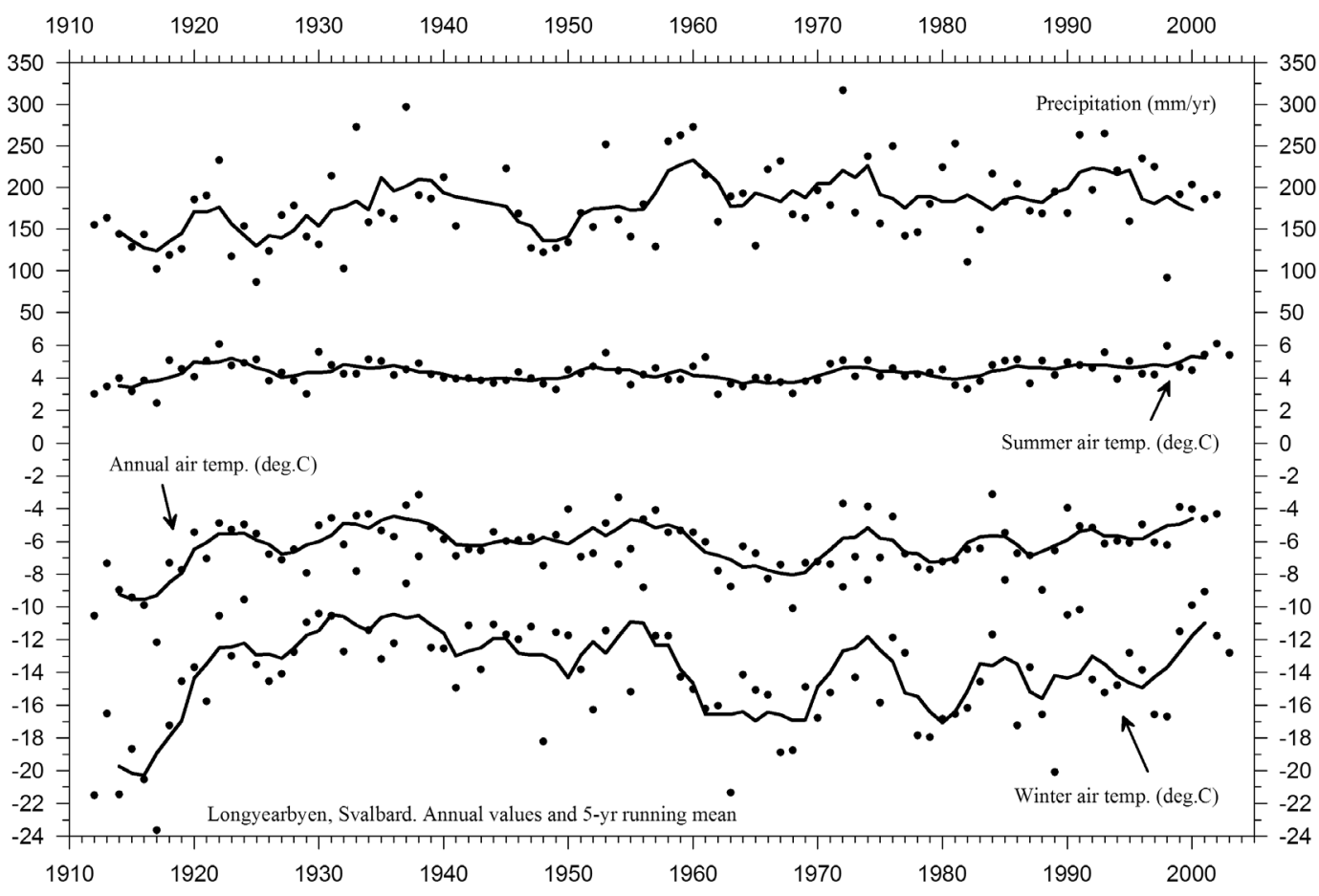

Fig. 2. Precipitation and mean annual air temperature at Longyearbyen since 1911, showing annual observations (points) and running 5 year average (solid lines). Summer is June-August. Winter is December-February. Data from Norwegian Meteorological Institute.

by O. Humlum. Modern meteorological values are within the range of variability defined by the total Svalbard meteorological record; the warmest period in the 20th century was around 19301940. The average vertical precipitation gradient on Spitsbergen is $15-20 \%$ (per $100 \mathrm{~m}$ ) in the coastal regions, while it is somewhat smaller $(5-10 \%)$ in the central part of Spitsbergen (Hagen \& Liestøl 1990; Hagen \& Lefauconnier 1995; Killingtveit et al. 1996). The coastalinland contrast in vertical precipitation gradient is assumed to be caused by enhanced orographic effects in the coastal regions compared to inland areas (Humlum 2002). As outlined below, this distribution of precipitation represents a control on permafrost development in Svalbard.

\section{Controls on present permafrost distri- bution in Svalbard}

Permafrost is a purely thermal phenomenon that involves ground temperatures not exceeding $0{ }^{\circ} \mathrm{C}$ for two continuous years (French 1996). Air temperature, topography, snow cover, wind, lithology, geothermal heat flow and distance to ocean are among the main factors in the distribution and thickness of permafrost on islands such as the Svalbard archipelago. Many of these factors are covered by the concept "topoclimate". This embraces all the complexities when ground surface climate is considered, rather than air climate. Primary influences on topoclimate include elevation, aspect, slope angle, vegetation cover, and the material making up the near-surface layer. In cold climates, a central role is also played by the seasonal snow cover in influencing both ground temperatures and ground moisture regimes (Ballantyne 1978). While recognizing their complexity, the direct effect of some of these variables is outlined below.

In the Svalbard context, in contrast to many lowland permafrost areas, topography is especially important as it relates both to differences in altitude and aspect. At high altitudes permafrost is usually thicker than in major valleys, as is dem- 
onstrated by mining activities (Liestøl 1976). This is partly due to lower air temperatures at higher altitudes, and partly due to enhanced cooling of mountain ridges or other topographic highs. Topographic-induced shadow in valleys may counteract this effect to some degree. Lithology is a control on geothermal heat flow, representing a major control on permafrost thickness. In Svalbard, below the depth of zero annual amplitude $(15-20 \mathrm{~m})$, the ground temperature increases by about $2-3^{\circ} \mathrm{C}$ per $100 \mathrm{~m}$ (Liestøl 1976; Isaksen, Vonder Mühll et al. 2000).

Low air temperature is important to keep the ground from thawing. From an empirical point of view, the mean annual air temperature usually has to be below $-2{ }^{\circ} \mathrm{C}$ to initiate widespread growth of permafrost (French 1996). Seasonal variations of temperatures are also important. Wind is also of importance as it determines where insulating snow accumulates during the winter and where the ground surface is kept free of snow. Beneath thick snow accumulations (or glaciers) permafrost is usually either shallow or even absent. The seasonal snow cover may also represent a source for soil moisture, which influences the thermal characteristics of the active layer downslope of snow accumulations (Humlum 1998). Variations in the timing and duration of seasonal snow cover are critical to the ground thermal regime because they change surface conditions and the associated ground surface energy balance.

Snow cover also has a direct effect on the distribution of permafrost on a local scale in Svalbard. In the central, more arid parts of Spitsbergen the average winter snow cover is thin and the ground surface cools efficiently during the winter. By contrast, in the more maritime western and eastern parts, the snow cover is thicker (Humlum 2002; Hagen et al. 2003) and therefore reduces heat loss from the ground surface during winter. Especially in the eastern and southern parts of the archipelago, considerable amounts of snow may accumulate on the landscape by snowdrift derived from upwind sea ice areas (Humlum 2002). Interannual variations in the establishment of the snow cover are also important. A dry and cold autumn enables enhanced cooling of the active layer and topmost permafrost. High snowfall during late winter and late onset of snow melt protect the ground against thawing in early summer. The combination of these two meteorological phenomena is beneficial for the conservation and growth of permafrost, as recently exem- plified by the winter $2002 / 03$. Variations in the timing and duration of seasonal snow cover presumably also have an influence on active layer thickness, but the effect is still not known in detail (Christiansen et al. 2003).

Distance to the ocean or other major water bodies is also important, as water bodies represent a major source of heat. Permafrost is therefore shallow $(<100 \mathrm{~m})$ close to the shore. Also, thermal effects of major lakes or rivers may be considerable, tending to reduce permafrost thickness below or near such water bodies.

\section{A long-term perspective on permafrost in the Arctic}

Polar climate today is cold and permafrost widespread, but this has not always been the case. The record of global climate variations during the Phanerozoic (past $545 \mathrm{My}$ ), based on temporal and spatial patterns of climate sensitive sedimentary indicators (Shaviv \& Veizer 2003), shows intervals of tens of millions of years duration, characterized by predominantly colder or predominantly warmer episodes, called icehouses and greenhouses (Frakes et al. 1992), respectively. Growing evidence, such as the correlations between palaeoclimate records and solar and cosmic ray activity indicators (e.g. ${ }^{10} \mathrm{Be}$, ${ }^{14} \mathrm{C}$ ), suggests that extraterrestrial phenomena are important drivers for climatic variability on time scales ranging from days to millennia (FriisChristensen \& Lassen 1991; Tinsley \& Deen 1991; Soon et al. 1996; Svensmark 1998; Soon et al. 2000; Björck et al. 2001; Bond et al. 2001; Pang \& Yau 2002; Solanki 2002).

Reconstructions of Tertiary surface temperatures are still somewhat tentative. It is clear, however, that the persistent cooling which ultimately led to the Quaternary glaciations did not commence until about 33 Mya, in Oligocene times (Zachos et al. 2001). The gradual closing of the connection between the Pacific and the Arctic Ocean by continental drift gradually reduced the previously efficient ocean heat transport from equatorial regions toward the North Pole, and the Northern Hemisphere experienced cooling. The Greenland ice sheet presumably formed about 7 Mya (Zachos et al. 2001). Formation of the first major permafrost regions at low altitudes was presumably contemporary with the first major glaciations. 


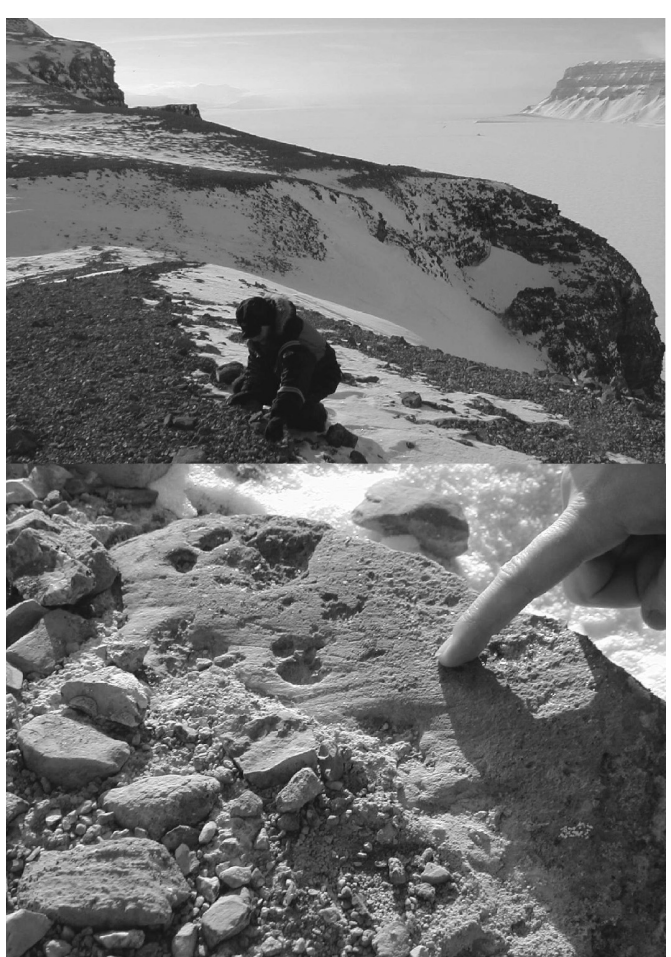

Fig. 3. Weichselian glacial striae on bedrock exposure (195 $\mathrm{m}$ a.s.1.) above Tempelfjorden, central eastern Spitsbergen, March 2002. Such striae suggest Weichselian glaciers to have been warm-based, at least for part of the glaciation.

Atmospheric chemical changes may have contributed to the Tertiary cooling trend. Over geological time, the amount of atmospheric $\mathrm{CO}_{2}$ represents a balance between release by volcanic activity and rock metamorphism, and uptake by bedrock weathering reactions. High rates of sea floor spreading are associated with widespread active volcanism, orogenesis and rock metamorphism, leading to higher atmospheric $\mathrm{CO}_{2}$ content, resulting in warmer global climate. Conversely, in intervening periods of relatively low rates of sea floor spreading, uptake of atmospheric $\mathrm{CO}_{2}$ by bedrock weathering processes dominate, and global climate consequently cools. The global cooling experienced following the Alpine orogenesis in Cretaceous and early Tertiary times may partly result from this (Summerfield 1983, 1991). In addition, geological mechanisms involving phases of regional uplift and erosion may also have been instrumental in the development towards cooler climate and permafrost growth (Japsen \& Chalmers 2000).
Orbital influences were also important in Tertiary cooling (Milankovitch 1930, 1941; Imbrie \& Imbrie 1979; Imbrie et al. 1984; Miller et al. 1991). Marine stable isotope records show a strong 40000 periodicity, consistent with a high latitude orbital (obliquity) control on global ice volume and temperature (Zachos et al. 1997). Orbital influences were also apparent at precession and eccentricity frequencies, although not as clear as that derived from obliquity variations.

By 3.5 Mya, the climate of the Northern Hemisphere had cooled considerably, as reflected in the oxygen isotope record of marine cores (Ruddiman et al. 1986; Raymo 1992; Harris 2002). The stage was set for subsequent massive Quaternary glaciations and widespread establishment of permafrost. The global cooling culminated in a series of step-like, sudden, changes in climatic conditions over the last $2.6 \mathrm{My}$, and a series of recurrent shifts between glacial and interglacial conditions began (Jansen \& Sjøholm 1991). From interpretations of ocean cores and long sequences of loess, it is apparent that no less than 30-40 glacial cycles have affected the Earth's surface during the Quaternary (Dansgaard \& Tauber 1969; Kukla 1987; Imbrie et al. 1993). Very thick permafrost (1 - $1.5 \mathrm{~km})$, such as found in unglaciated parts of Siberia, presumably grew throughout most of the Quaternary.

\section{Age of Svalbard permafrost}

In Svalbard, permafrost is typically is about $100 \mathrm{~m}$ thick in major valley bottoms and up to about 400-500 $\mathrm{m}$ thick in the high mountains (Liestøl 1976).

During the Weichselian period most of Svalbard was covered by thick glacial ice. Opinions differ as to the size and extent of the ice cover. Glacial striae (Fig. 3) in several main valleys suggest that Weichselian glaciers grew to sufficient thickness to reach the pressure melting point at the glacier sole, enabling basal sliding, even though surface air temperatures at that time were probably significantly below present values. During the Weichselian, pre-existing permafrost in deep valleys would have been exposed to thaw both from above (frictional heat generated by basal glacier sliding) and below (geothermal heat). Adopting typical values for both frictional heat generated by glacier sliding and geothermal heat flow; the combined effect would have been the thaw 
of about $1 \mathrm{~cm}$ of permafrost per year (Weertman 1969). A typical glacial period is about 100 Ky long, but only for shorter periods does a significant glacier cover grow to large (continental) size. Taking $30 \mathrm{Ky}$ as an order of magnitude for the duration of extensive glaciation in the Svalbard region, this would generate a thaw of about $300 \mathrm{~m}$ of permafrost during the Weichselian. If surging glaciers or rapid ice streams occurred in Svalbard during the Weichselian, energy dissipated by glacier sliding would have caused additional thawing of permafrost beneath valleys affected by such glaciers. This signals that, while permafrost in the main trunk valleys may have been eliminated during many Quaternary glaciations, some of the permafrost found beneath the highest elevations may be of considerable antiquity, perhaps as much as $700 \mathrm{Ky}$. Depending on Weichselian maximum ice extension and thickness, some permafrost in the western coastal regions of Svalbard may also be of pre-Holocene age where the existence of ice-free areas have recently been demonstrated (Landvik et al. 2003).

A late Holocene age of permafrost near present sea level in central Spitsbergen is indicated by the dating of both pingo and ice wedge initiation (Svensson 1971; Jeppesen 2001). Ronnert \& Landvik (1993), working at the glacier Albrechtbreen, on Edgeoya, suggested from lithological differences between moraine ridges, that the first ice advance following the early Holocene warm period occurred during a period with limited permafrost, whereas permafrost was more extensive during the subsequent glacier advance during the Little Ice Age.

\section{Svalbard permafrost compared to other permafrost areas}

Today glaciers cover ca. $60 \%$ of the total land area of Svalbard, leaving $40 \%$ to the periglacial environment and permafrost. This amounts to a permafrost surface area of about $25000 \mathrm{~km}^{2}$. Thus, Svalbard represents the largest permafrost area in Europe outside of Russia.

In contrast to some other regions with extensive permafrost, such as Siberia and northern Alaska, much permafrost in Svalbard is presumably of young (i.e. Holocene) age. It tends to have been thawed during the recurrent Quaternary glaciations. High altitude permafrost in Svalbard may represent an exception to this. Another contrast

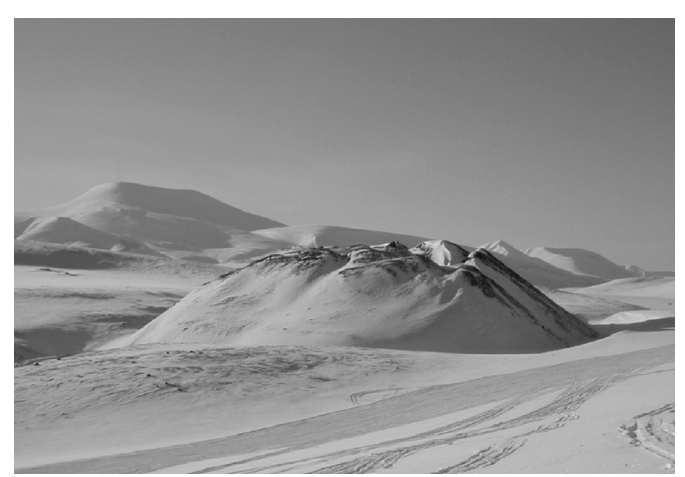

Fig. 4. Pingo in upper Eskerdalen, near Brentskardet, central Spitsbergen. The pingo is raised about $25 \mathrm{~m}$ above the valley floor and is, presumably, of the open-system type.

between Svalbard permafrost and extensive lowland permafrost lies in the surface relief. In Svalbard the mountain topography introduces local, large variations in ground temperature regime and permafrost thickness due to variations in slope, aspect, altitude, topographic shading and redistribution of the winter snow cover by wind. As a result, permafrost in Svalbard is presumably more sensitive to changes in temperature and thickness than is the permafrost of extensive lowlands in Siberia, northern Canada and Alaska. In addition, Svalbard is an archipelago located near the northernmost branches of the North Atlantic Current and the southern limit of polar pack ice. Even small variations in these important phenomena will induce rapid climatic variations with potential effects on the local Svalbard climate and permafrost not known from more continental permafrost regions.

\section{Svalbard geomorphic permafrost phenomena}

\section{Pingos}

Pingos represent a typical permafrost phenomenon in Svalbard (Fig. 4). The majority of pingos are found below the uppermost Holocene marine limit. They are formed by aggradation of permafrost in association with ice lensing or freezing of massive ice bodies within near-surface sediments. Intrusive ice or injection ice may form in two ways. First, water expelled ahead of the freezing front during freezing of coarse sediments may be intruded into adjacent unfrozen 
sediments, where it eventually freezes to form a massive body of ground ice. Second, sub-permafrost groundwater in areas of discontinuous permafrost may be injected under artesian pressure into unfrozen sediment. Subsequent freezing of the injected water again leads to the development of massive ground ice. In either case the resulting ice body may cause local lifting of the ground surface and the growth of a hill, called a pingo (local Inuit [Mackenzie Delta, Canada] name for hill or mound).

Pingos are generally circular or oval in plan. In Svalbard, they may achieve a horizontal extension of up to $500 \mathrm{~m}$ and heights of up to $40 \mathrm{~m}$. Pingos develop in bedrock and a variety of unconsolidated sediments, including till, slope deposits and alluvial silt, sand and gravel (Liestøl 1976). Pingos resulting from water expulsion during permafrost aggradation are termed closed-system pingos (Mackay 1972), while those fed by subpermafrost groundwater percolation are known as open-system pingos (Müller 1959). Most, if not all, pingos in Svalbard are of the open-system type (Liestøl 1976).

Many open-system pingos in Svalbard occur at or near the transition between slope sediments and valley-fill deposits (Liestøl 1996). Another typical location for open-system pingos in Svalbard is along the lower border of late Holocene alluvial fans. During winter, any remaining unfrozen water presumably flows in the lowermost layers of such coarse-grained deposits, on top of more impermeable permafrost below, until reaching the lower limit of the alluvial fan. Here, the water is forced towards the surface as the alluvial deposits thin, and is consequently exposed to rapid cooling and freezing. At certain sites, the overlying sediments are lifted in sufficient thickness to protect against summer melting and an open-system pingo formed. During the winter, it is common to see icing blisters forming along the lower rim of alluvial fans. Such phenomena represent seasonal features only and disappear during the following summer.

Lakes in unconsolidated sediments are rare in Svalbard. They might explain the apparent absence of closed-system pingos in Svalbard. The situation has a partly glaciological explanation because Svalbard, during the Quaternary glaciations, was an area of net glacial erosion. Thus, extensive and thick deposits of unconsolidated sediments are absent. Likewise, late Holocene relative land submergence due to the Neoglaci- ation and the lack of extensive delta plains further deprives Svalbard of extensive low-relief sediment areas like those found at typical sites of closed-system pingo formation (e.g. Mackenzie and Lena River deltas).

Liestøl (1976) observed a particular relationship between glaciers and open-system pingos in Svalbard. Permafrost is largely continuous, but many glaciers have a subpolar thermal regime, so permafrost extends only beneath their marginal zones. Beneath the warm-based ice in the central parts of glaciers, meltwater percolates into the unfrozen substrate and then migrates under hydrostatic pressure beneath the permafrost that underlies the glacier margins. In consequence, artesian pressures develop in sub-permafrost groundwater beyond the glacier margins, allowing the growth of open-system pingos in areas of thinner or weaker permafrost, such as close to the lower limit of alluvial fans. Reindalen, in central Spitsbergen, represents the type locality for such open-system pingos and displays a variety of active pingos in different stages of growth. Following Liestøl's line of thought, periods of pingo growth in Svalbard may, to some degree, take place in concert with major glacier advances, leading to local reorganization of ground temperatures and hydrological characteristics.

\section{Ice wedges}

A striking feature of many valley bottoms and sloping valley sides in Svalbard is the presence of polygonal networks formed by shallow troughs in the ground surface (Fig. 5). These polygons range from 15 to $50 \mathrm{~m}$ in diameter and are found on all major islands in the archipelago. The surface troughs mark the locations of ice wedges that extend 3-5 $\mathrm{m}$ downwards into the permafrost from the base of the active layer. Such ice wedges result from the repeated opening of tension cracks caused by thermal-contraction cracking during winter.

Ice wedges consist of vein ice, and typically take the form of vertical wedge-shaped dykes penetrating downwards into the permafrost. In Svalbard they may be between $10 \mathrm{~mm}$ and $5 \mathrm{~m}$ wide and usually penetrate $2-5 \mathrm{~m}$ into the permafrost. Lachenbruch (1962) provided a detailed analysis of the mechanism of ice wedge formation, based on the contraction theory first proposed by Leffingwell (1915). Cracking results in a polygonal network of vertical cracks that 
Fig. 5. Ice wedge furrows in lower Adventdalen, centra Spitsbergen, about $15 \mathrm{~m}$ a.s.1 The ice wedge net measures $5-15 \mathrm{~m}$ across.

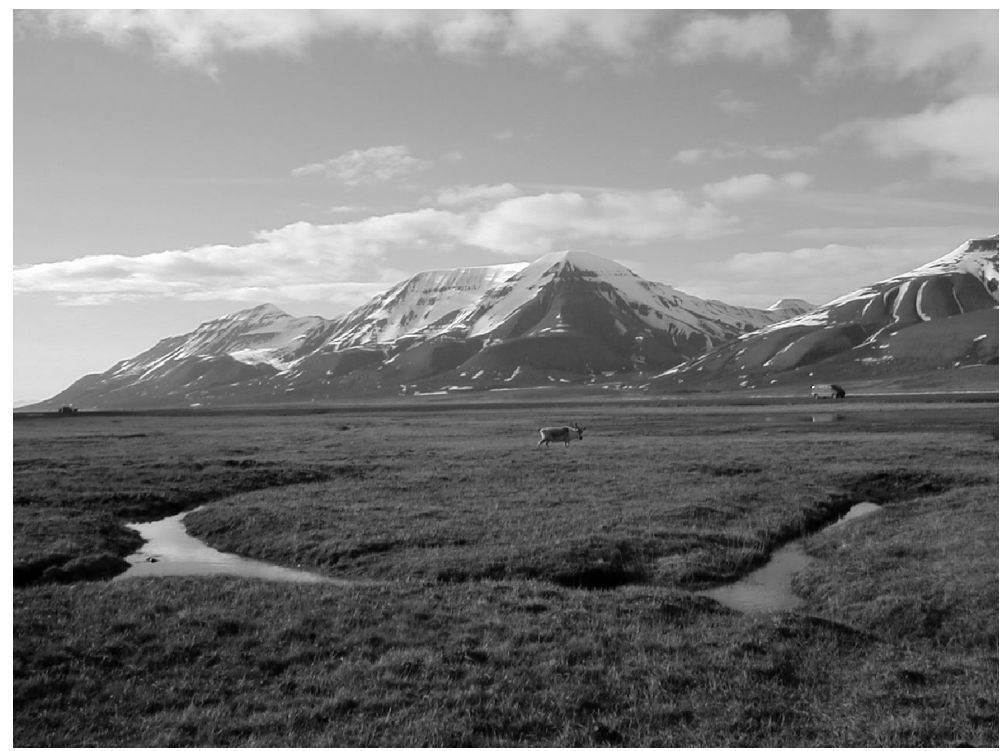

relieve tensile stress set up by such contraction. Meltwater percolates into them during spring to refreeze, preventing the cracks from closing fully as the permafrost warms and expands in summer. Since the tensile strength of ice is less than that of frozen sediment, thermal contraction cracks tend to reopen along the pre-existing network of ice veins in subsequent winters. Ice wedges thereby grow incrementally as each successive phase of contraction cracking is accompanied by filling of the open crack with more ice.

The incremental growth of ice wedge produces foliation parallel to the sides of the wedge. Such foliation is due to aligned ice crystal fabrics and the incorporation of air bubbles and silt layers. Many ice wedges are typically 1-3 m wide and penetrate $3-5 \mathrm{~m}$ below the permafrost table. The polygons generally range from $15 \mathrm{~m}$ to $50 \mathrm{~m}$ in diameter. Their plan form may be roughly hexagonal with angles tending to approximate $120^{\circ}$, or orthogonal with a tendency towards $90^{\circ}$ junctions.

In Svalbard, ice wedges have been observed mainly in large valleys such as Adventdalen, Colesdalen and Reindalen-all in central Spitsbergen - and Sassendalen, in southern Spitsbergen, but also at some sites in the uplands surrounding the valleys (Sørbel et al. 2000: Tolgensbakk et al. 2001). From the Adventdalen area, Sørbel \& Tolgensbakk et al. (2001) and Sørbel et al. (2001) report that ice wedges are common, occurring on both flat terrain and on slopes up to $25^{\circ}$, and up to altitudes about $500 \mathrm{~m}$ a.s.l. Ice wedges above $250 \mathrm{~m}$ a.s.1. are typically developed in weathering material of Cretaceous age, whereas in the valley bottoms they are mainly found in fluvial or glaciofluvial sediments (Sørbel \& Tolgensbakk 2002).

Relatively little research has been carried out on Svalbard ice wedges. Svensson (1976) investigated ice wedges in Adventdalen in the summers of 1968 and 1972 and found evidence for the investigated ice wedges being active. He particularly noted that a small ice dome at that time was forming in the central cracking part of ice wedges, indicating that the active layer thickness has been thinning during the previous years. This development was explained partly by a lowering of the mean annual air temperature from $-5.9{ }^{\circ} \mathrm{C}$ prior to 1968 and to $-6.3^{\circ} \mathrm{C}$ in 1972 . Matsuoka (1999) reports similar phenomena observed at ice wedges in Adventdalen, based on two excavations carried out in 1992. He explained the secondary ice dome as having either grown along with loess deposition (i.e. syngenetic origin) or as reflecting an episodic thaw penetration several decades ago, presumably during the extraordinarily warm summers of 1922 and 1930 that followed the main 20th century warming event around 1920 .

Thermal-contraction cracking at an ice wedge site in Adventdalen was monitored in the period 1990-92 (Matsuoka 1999). The amount of contraction was found to be proportional to the magnitude of the minimum temperature. A maximum 


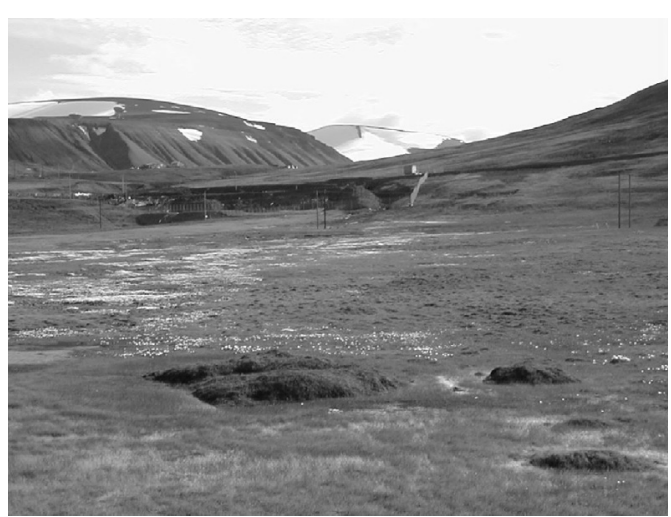

Fig. 6. Small palsas in Adventdalen, central Spitsbergen, below Gruve 6 (mine 6).

of $16 \mathrm{~mm}$ separation was measured over the ice wedge when a minimum winter ground surface temperature of $-27.3^{\circ} \mathrm{C}$ was registered, while the temperature at the permafrost table was $-17.1^{\circ} \mathrm{C}$. Based on summer observations, Matsouka (1999) reported a $15 \%$ cracking frequency of ice wedges in the Adventdalen area.

Recently the $\delta \mathrm{O}^{18}$ variation in three ice wedges in Adventdalen was analysed with respect to Late Holocene palaeoclimatic variations (Jeppesen 2001). A broadly similar isotope variation was found across the ice wedges, suggesting that Svalbard ice wedges may contain important palaeoclimatic information. No direct dating of the observed $\delta \mathrm{O}^{18}$ variations was possible, but organic material found in the outer (older) part of one of the ice wedges yielded an age of about $2900 \mathrm{cal}$. yr BP using the ${ }^{14} \mathrm{C}$ accelerated mass spectrometer technique (Jeppesen 2001). As the sample came from the outer part of the ice wedge, the age is interpreted as a maximum age of the ice vein containing the organic material; this indirectly provides the approximate maximum age of the ice wedge (Jeppesen 2001). This age corresponds rather well with the maximum age of $2650 \pm 55 \mathrm{yr}$ BP from driftwood found on the top of the Longyearpingo (Svensson 1971), only $3 \mathrm{~km}$ from the ice wedge site investigated. It appears, therefore, that permafrost, pingos and ice wedges in the main valleys such as Adventdalen are about 3000 years old (Christiansen 2003). On the other hand, Sørbel \& Tolgensbakk (2002) suggest that some of the ice wedges found at higher altitudes may be pre-Weichselian and could possibly have been preserved below cold-based ice.

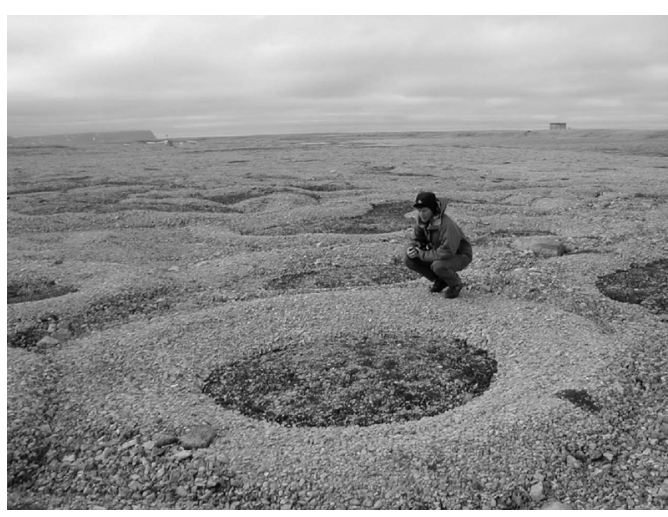

Fig. 7. Sorted circles at Kvadehuksletta, Brøggerhalvøya, north-west Spitsbergen.

\section{Palsas}

Palsas are permafrost peat mounds that usually occur in regions of discontinuous permafrost. They are not very frequent in High Arctic Svalbard (Salvigsen 1977; Åkerman 1982), but are usually found in sub-Arctic permafrost areas such as northern Scandinavia. The typical palsa takes the form of a peat mound rising from the surface of a fen (Fig. 6). Palsas are produced by downward freezing from the ground surface, enhanced by a thin snow cover on the palsa compared to the surroundings. Ice in palsas does not form solid bodies of ice, but only millimetre-thick lenses of ice. Their maximum dimensions are about $5-7 \mathrm{~m}$ high and 50-100 m across. Palsas in Svalbard are usually much smaller, only $0.5-1 \mathrm{~m}$ high. A few examples of palsas are found in lowermost Adventdalen in wet areas rich in vegetation.

\section{Sorted circles}

Patterned ground in the form of 2-10 m sorted circles represents active layer phenomena, and is widespread on level ground in Svalbard (e.g. Åkerman 1987; Etzelmüller \& Sollid 1991). Sorted circles cover many mountain plateaus and coastal flats (Fig. 7), signalling the presence of permafrost below, even though the detailed origin of patterned ground is not yet fully clear. Washburn (1956) was able to list no less than 19 different hypotheses for patterned ground development. Most scientists tend to agree, however, that patterned ground presumably arises due to the combined effect of frost-heave, thaw settlement, consolidation and differential movements due to 
recurrent growth and melting of small (segregated) ice lenses in the active layer. All these processes are frequently combined under the general heading of cryoturbation.

Fine examples of patterned ground (sorted circles) are found at Kvadehuksletta, north-western end of the Brøggerhalvøya peninsula at $79^{\circ} \mathrm{N}$, $12^{\circ} \mathrm{E}$. Tolgensbakk \& Sollid (1987) mapped the geomorphology and Quaternary geology of this area. Fields of sorted circles occur especially in depressions between raised beach ridges, probably due to high soil water content and precense of fine-grained sediment, leading to an enhanced frost action environment (Etzelmüller \& Sollid 1991). From detailed studies of the dynamics of well-developed sorted circles, Hallet \& Prestrud (1986) and Hallet et al. (1988) conclude that motion in the sorted circles includes convection in fine-grained centre and "subduction" in the fine/coarse contact. A model for self-organization of sorted patterned ground has recently been proposed by Kessler \& Werner (2003), drawing upon examples from Kvadehuksletta. Another fine example of sorted circles was reported by Jahn (1975) from Hornsund, in southern Spitsbergen. It is interesting to note that both Kvadehuksletta and the Hornsund site are dominated by weathering residuals of dolomite bedrock.

\section{Rock glaciers}

Rock glaciers are characteristic large-scale flow features of frozen material in permafrost highrelief regions (Haeberli 1985; Barsch 1996; Humlum 1999; Isaksen 2001). They are located at the foot of rock-free faces with a high supply of talus and, when active, typically take the form of 20-100 m thick tongue- or lobe-shaped bodies with cascading frontal slopes standing at the angle of repose (Fig. 8). Their length may be as much as several kilometres, but the typical length is $200-800 \mathrm{~m}$ measured parallel to the flow direction (Barsch 1996). The surface of rock glaciers is covered by coarse $(0.2-5 \mathrm{~m})$ rock fragments, and displays a $1-5 \mathrm{~m}$ high curving transverse furrowand-ridge topography. Active rock glaciers typically flow downslope 0.1-1 m per year (see e.g. Barsch 1996), that is, they are more sluggish than normal glaciers. Active rock glaciers are often seen as characteristic of continental environments, although a significant number of rock glaciers have been described from maritime regions as well (e.g. Sollid \& Sørbel 1992; Humlum

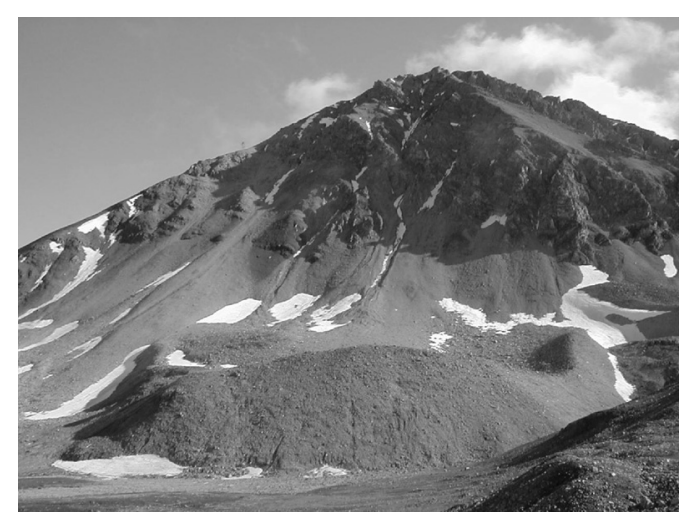

Fig. 8. Talus-derived rock glacier creeping from the talus sheet on Zeppelinfjellet, near Ny-Ålesund, north-west Spitsbergen. The rock glacier terminus is about $35 \mathrm{~m}$ high.

2000). The topographic and meteorological controls on rock glacier initiation and growth are still not known in detail, and a long-standing discussion on rock glacier origin, internal structure, rheology and nomenclature has originated from this lack of field knowledge. Most scientists agree that rock glaciers are the result of a localized, large supply of talus in a permafrost environment. In addition, rock glaciers represent a highly efficient transport system of weathered debris in highrelief, cold climate regions (Humlum 2000).

Rock glaciers of different morphological type are widespread in Svalbard (e.g. Sollid \& Sørbel 1992; André 1994; Berthling et al. 1998; Isaksen, Ødegård et al. 2000; Isaksen 2001; Korsgaard 2002), and many of these conspicuous landforms presumably derive from accumulation of avalanche snow on talus sheets, giving rise to aggrading permafrost consisting of a mixture of ice and rock fragments (Liestøl 1962). An aerial photograph inventory of Svalbard rock glaciers (Kristiansen \& Sollid 1986) revealed the existence of more than 500 rock glaciers. Many are found in coastal areas, situated below the escarpment that delimits the inner part of the strandflat. Rock glaciers are particularly frequent along the extreme western and northern coast of the largest island, Spitsbergen, and on Prins Karls Forland, a small island off western Spitsbergen (Sollid \& Sørbel 1992). Svalbard rock glaciers are generally less than $60 \mathrm{~m}$ thick and less than $500 \mathrm{~m}$ long. The permafrost base is presumably far beneath the base of these features, as permafrost thickness is estimated to vary from about $100 \mathrm{~m}$ near the coasts to more than $450 \mathrm{~m}$ in mountain areas 
(Liestøl 1976).

Surface velocities of Svalbard rock glaciers are known to range from no significant movement to $10 \mathrm{~cm} /$ year (Sollid \& Sørbel 1992; Isaksen, Ødegård et al. 2000; Kääb et al. 2002). Measurements from talus-derived rock glaciers on Prins Karls Forland show that most surface velocities are within the range of $1-4 \mathrm{~cm} /$ year based on carrier-phase differential GPS measurements (Berthling et al. 2001).

The age of Svalbard rock glaciers is not known in detail and current age estimates of Svalbard rock glaciers are therefore coupled to the Late Weichselian glacial history. The maximum extent of the Svalbard Weichselian ice cover, especially along the west coast of Spitsbergen, has been a matter of debate. A recent reconstruction of the Late Weichselian maximum ice sheet suggests more than $800 \mathrm{~m}$ of Weichselian ice cover at Prins Karls Forland and the west coast of Spitsbergen (Landvik et al. 1998). In contrast, another study from central Prins Karls Forland (Andersson et al. 1999) presents evidence of a much more limited expansion of local glaciers during the Late Weichselian.

These findings introduce uncertainty about the age and possible onset of rock glacier development in the outermost western part of the archipelago. In addition, there is uncertainty regarding the extension of permafrost at low altitudes during the Holocene climatic optimum. It has been suggested that most rock glaciers probably started to develop at the onset of Holocene, and that even older forms cannot be ruled out (Sollid \& Sørbel 1992; Kääb et al. 2002). Some very large rock glaciers are apparently located in areas that may have been ice-free for a long period, perhaps as much as $40 \mathrm{Ky}$. Western Prince Karls Forland is one such location. Here, some of the largest rock glaciers in all Svalbard are found (Liestøl 1962; Berthling et al. 1998; Berthling et al. 2000). However, André (1994), based on lichenometry, suggested that rock glacier formation in the Kongsfjorden area, north-west Spitsbergen, started ca. $3500 \mathrm{BP}$, while Isaksen, Ødegård et al. (2000) estimated the age of the surface material at the terminus of Hiorthfjellet rock glacier, central Spitsbergen, to about 4000 BP. This age estimate was based on the length/surface velocity ratio, assuming constant flow velocity since rock glacier initiation. Finally, existing knowledge on Holocene climate in the Svalbard region (see e.g. Salvigsen et al. 1992; Svendsen \& Mag- nerud 1997; Snyder et al. 2000) support a late Holocene aggradation of permafrost at low altitudes and subsequent formation of several Svalbard rock glaciers. A detailed understanding of the onset of rock glacier formation in Svalbard, however, remains slightly elusive and awaits further research.

\section{Permafrost engineering}

\section{General}

A structure placed on, or in, permafrost in Svalbard will alter the heat exchange between the ground and the atmosphere and will, in most cases, result in increased heat flow from the atmosphere to the soil. Removal of the organic layer for the foundation construction and snow accumulation around, under and adjacent to the structure, and heating of the structure may enhance this effect. The physical and mechanical properties of permafrost are generally temperature dependent and this effect is most pronounced at temperatures within 1 or $2^{\circ} \mathrm{C}$ of thawing (Ladanyi et al. 1996). Increases in permafrost temperature will, in general, lead to deteriorating strength and deformation characteristics, potential accelerated settlements and possible foundation failure (see Instanes 2003). It is of paramount importance, therefore, that an evaluation of the thermal effect of an engineering structure is taken into account in planning, design, construction and maintenance of structures in Svalbard and in the Arctic in general.

Most of the engineering concerns related to the design of infrastructure on ice-rich permafrost can be classified into those related to increases in permafrost temperatures, increases in the active layer thickness (annual thaw depth) and degradation of permafrost.

Warming of permafrost at depth will cause an increase in the creep rate of existing foundations such as piles and footings, increased creep of embankment foundations and eventual loss of adfreeze bond support for piling. Increases in annual thaw (active layer) will cause increased thaw settlements during seasonal thawing, increased frost-heave forces on pilings and increased total and differential frost heaving during winter. Development of residual thaw zones (taliks) will cause decrease of effective length of piling in permafrost, progressive land- 


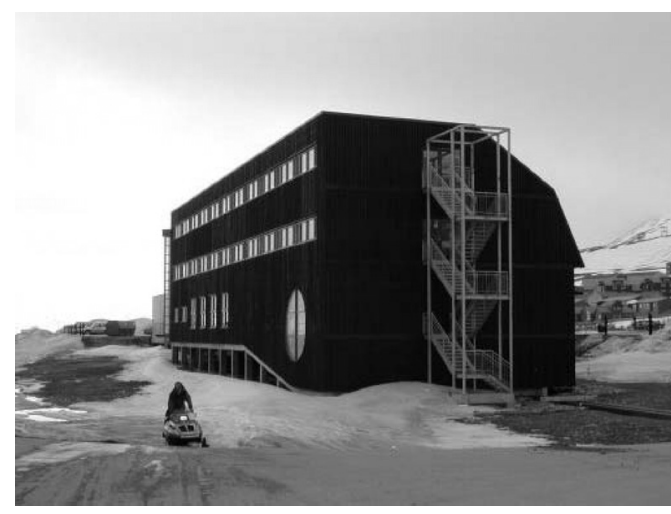

Fig. 9. University Centre in Svalbard, Longyearbyen. Foundation: excavation, replacement and concrete footings.

slide movements and progressive surface settlements (Esch \& Osterkamp 1990).

Design of foundations in permafrost regions must, therefore, always include an evaluation of the maximum active layer thickness and the permafrost temperature the foundation soils will experience during the lifetime of the structure. The initial and long-term bearing capacity of the foundation can then be determined (Instanes 2003).

\section{Registered thaw settlements on Spitsbergen}

There are five main settlements on Spitsbergen: Ny-Ålesund (north-west Spitsbergen), Pyramiden (central Spitsbergen), Longyearbyen (central Spitsbergen), Barentsburg (west Spitsbergen) and Sveagruva (central Spitsbergen). All these settlements were founded as coal mining towns, but today only Sveagruva and Barentsburg are solely dependent on the mining industry. Ny-Ålesund has developed into a Largescale Research Facility and has between 40 and 100 inhabitants, depending on the season. With a population of more than 1700, Longyearbyen depends on tourism, research and education in addition to mining. Ny-Ålesund, Longyearbyen and Sveagruva are Norwegian settlements. Each of the Russian mining settlements of Barentsburg and Pyramiden had more than 1000 inhabitants, but there has been some decline in population in Barentsburg the last couple of years. Pyramiden was abandoned in 1998.

The major parts of the engineering structures in the settlements have been designed and constructed during the last 30 years. There are char-

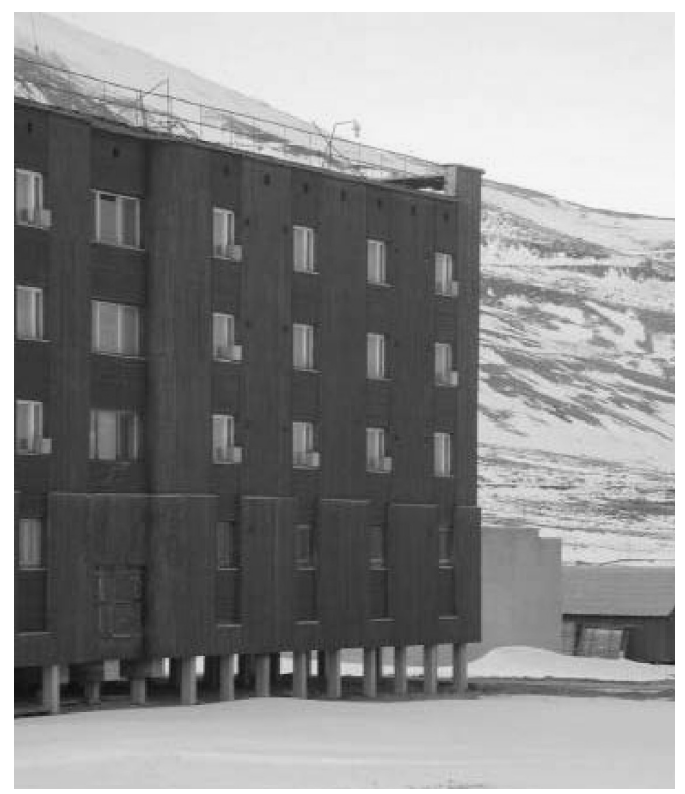

Fig. 10. Housing in Pyramiden. Foundation: reinforced concrete piles.

acteristic differences between the building style in the Russian and Norwegian settlements. In the Norwegian communities, the buildings are seldom more than $2 \frac{1}{2}$ storeys high, to minimize the loads and the number of foundation piles necessary (Fig. 9). In the Russian communities, the buildings can be more than 4 storeys high and therefore require a large number of piles for support (Fig. 10).

\section{Design issues}

In principle there are three main approaches to foundation design on permafrost, based on soil conditions and the ground thermal regime (Instanes 2000; Andersland \& Ladanyi 1994): conventional design (referred to as Principle $\mathrm{I}$ in Russia); passive method (Principle II in Russia); and active method.

Conventional design similar to temperate climate is used when the soil materials are thawstable, i.e. only small volume changes of the foundation soils occur during warming or thaw of the soils.

Both the passive and active methods are employed when the soil materials are thaw-unstable, i.e. a significant volume change of the foundation soils will take place during warming or thaw of the soils. In the passive approach, the existing 


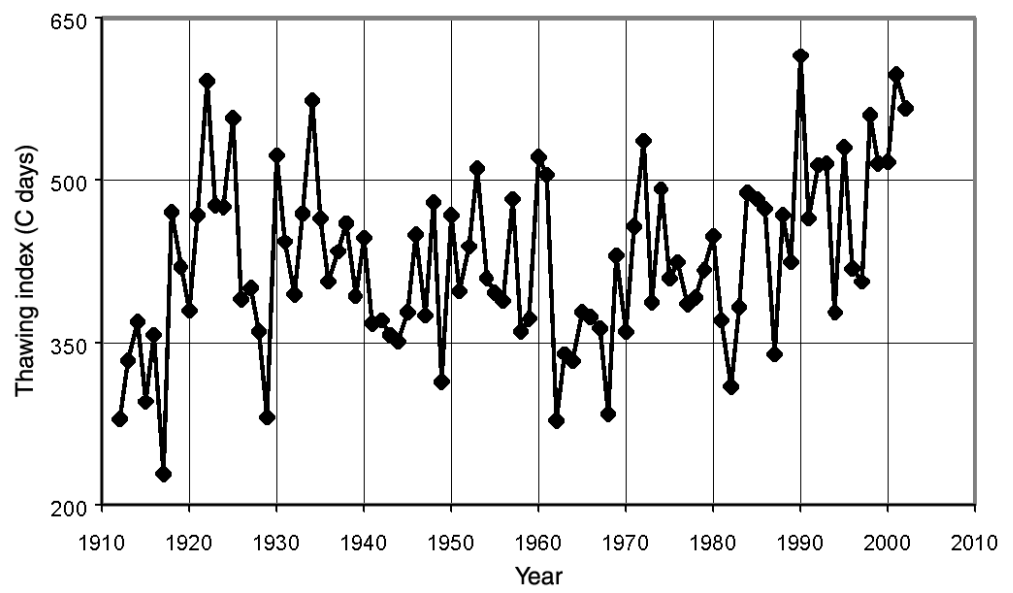

Fig. 11. Historical air-thawing indices (degree days thawing) for Svalbard Airport, Longyearbyen.

ground thermal regime is maintained (or ground temperature lowered) after the construction of the structure. In the active approach, warming of the existing ground thermal regime is accepted after the construction of the structure.

All three approaches have been used in Svalbard, but the passive method is the preferred approach for most engineering structures built on permafrost on the islands.

Design criteria for foundations on permafrost should be based on the probability of occurrence of the warmest air temperatures to which the foundation soils will be subjected during the lifetime of the structure (Instanes 2001, 2003). Thermal analysis of the structure, the foundation and the permafrost soils are usually carried out based on statistical analysis of historical meteorological data. The key parameters are the air-thawing index (the integral of air temperatures above $0^{\circ} \mathrm{C}$ during one summer) and air-freezing index (the integral of air temperatures below $0^{\circ} \mathrm{C}$ during one winter). Historical air-thawing and air-freezing indices for Longyearbyen are presented in Figs. 11 and 12. From the diagrams it might be observed that there has been a trend of increasing thawing indices (warmer summers) and decreasing freezing indices (warmer winters) during the last 20 years.

\section{Failure and damage to infrastructure}

Construction activity may lead to warming of the permafrost and to the damage and failure of foundation soils and structures. There is also increased concern related to the effect of possible climate change on infrastructure in the Arctic
(Instanes 2003; Khrustalev 2000, 2001; Ladanyi 1995, 1996; Ladanyi et al. 1996; Ladanyi et al. 1997; Lunardini 2001; Nixon 1990a, 1990b). For structures on permafrost it is often difficult to differentiate between the effect of possible climate warming and other factors that may affect a structure on permafrost, such as (Instanes 2003):

- Actual site conditions are different than the site conditions assumed during design.

- The design of the structure did not take into account appropriate load conditions, active layer thickness and permafrost temperature.

- The contractor did not carry out the construction according to the design.

- The maintenance programme was not carried out according to plan.

- The structure is not used according to design assumptions.

An example of problems associated with the factors listed above is the runway at Svalbard Airport, Longyearbyen (Instanes \& Instanes 1998; Mjureke 2001). This runway is built in an east-west direction and is $2322 \mathrm{~m}$ long and $45 \mathrm{~m}$ wide. In addition, there is a $37.5 \mathrm{~m}$ wide shoulder on each side of the runway $(7.5 \mathrm{~m}$ is paved; the rest has a gravel surface). The terrain slopes perpendicularly to the direction of the runway from the south towards the north. A system of drainage ditches direct water from the upslope side through the runway. Since the opening of the airport in 1975, the runway has suffered from unevenness of the surface due to thaw settlement in the spring/summer, and frost-heave during autumn/winter. Measurements have shown that the active layer beneath the runway is up to twice the design value of $1.1 \mathrm{~m}$. 
Fig. 12. Historical air-freezing indices (degree days freezing) for Svalbard Airport, Longyearbyen.

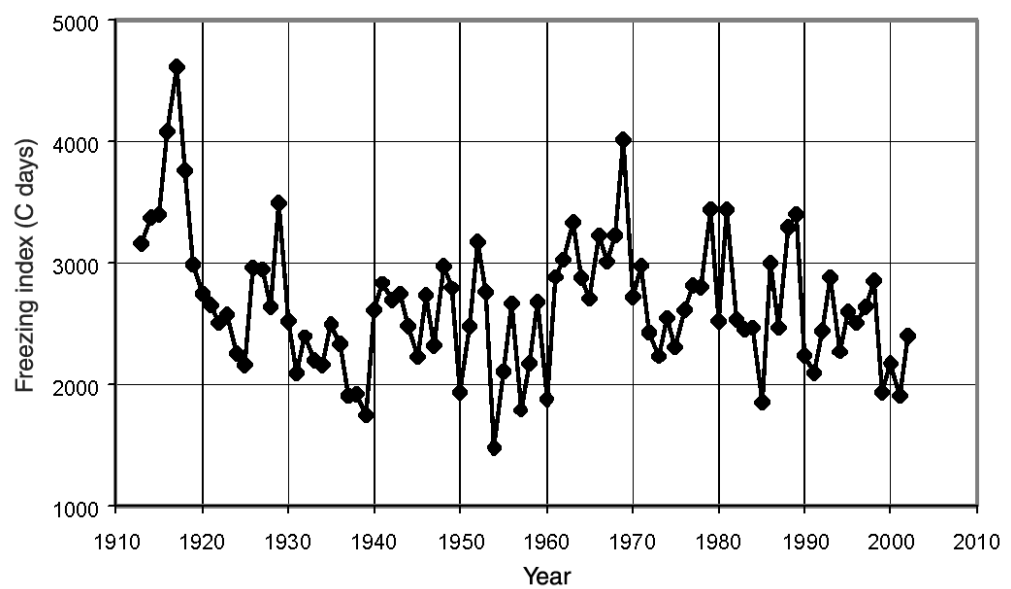

In 1989 a major reconstruction of the runway was carried out in the most affected areas. In addition to shifting soil and fill in the embankment, a $100 \mathrm{~mm}$ layer of polystyrene insulation was installed $650 \mathrm{~mm}$ below the runway surface. A ground temperature monitoring programme was established in 1992 to evaluate the effect of the reconstruction. Comparing temperature data from boreholes in insulated and unaltered sections of the runway, it was found that the active layer thickness was $1.3 \mathrm{~m}$ less in the insulated areas. The thaw depth in the non-insulated areas reached a maximum of $2.3 \mathrm{~m}$ in November. It was, therefore, recommended to insulate the remaining parts of the runway. This has not been carried out to date; fortunately, the problems seem to have decreased with time.

Instanes \& Instanes (1998) pointed out several factors that contribute to the problems with the runway. Among these were the facts that the runway was cut directly into ice-rich, frost-susceptible sediments, marine sediments (salty) were used as fill material and no insulation measures were taken.

\section{Permafrost engineering research and development}

Of special interest in permafrost engineering research and development for the last 30 years has been saline permafrost, ice-rich permafrost and coastal permafrost (Lunne \& Eidsmoen 1988; Instanes 2000). Under conditions such as encountered in Svalbard, it is recommended to artificially lower the ground temperature by heat pumps (Instanes 2000), thermosiphons (Anders- land \& Ladanyi 1994) or convection embankments (Goering \& Kumar 1996).

Research has also been carried out at the permafrost research station at Sveagruva (central Spitsbergen) that was established by the Norwegian Committee on Permafrost in June 1978 (Gregersen 1980). The station records hourly air temperature and humidity, wind force and direction, incoming and outgoing radiation, global radiation, ground temperature down to $8 \mathrm{~m}$ below the tundra surface, and ground temperature down to $2 \mathrm{~m}$ below an artificial concrete surface. The data series from 1978-2000 was analysed by Caline (2000). Figure 13 presents a plot of ground temperature at $1.0 \mathrm{~m}$ depth from 1978-1995 compared to a thermal model developed by Caline (2000). From this figure it can be observed that the minimum temperature during each annual cycle varies considerably while the maximum temperature is relative stable. The minimum temperature variation is influenced by variations in the winter snow cover. For engineering purposes, the main interest is, however, the maximum ground temperature - a late summer phenomena, so the variation shown in Fig. 13 has very little engineering significance.

One of the more challenging engineering efforts near Sveagruva is the construction of the road from the mining settlement to the new coalmine by the mining company Store Norske Spitsbergen Gruvekompani. The road utilizes the mid-moraine on the Höganäs glacier as a foundation for the road embankment (Fig. 14). The surface elevation of the road embankment and adjacent glacier was measured by differential global position system (DGPS) in both June and Sep- 


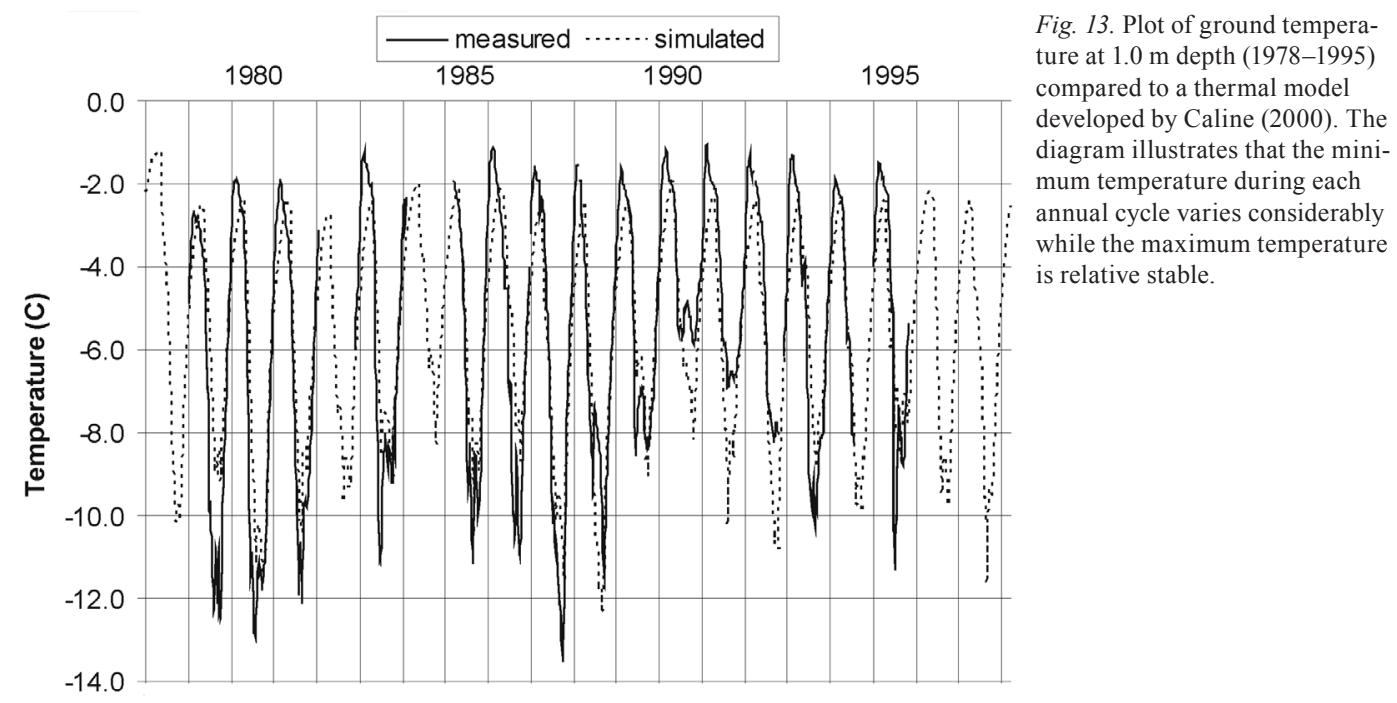

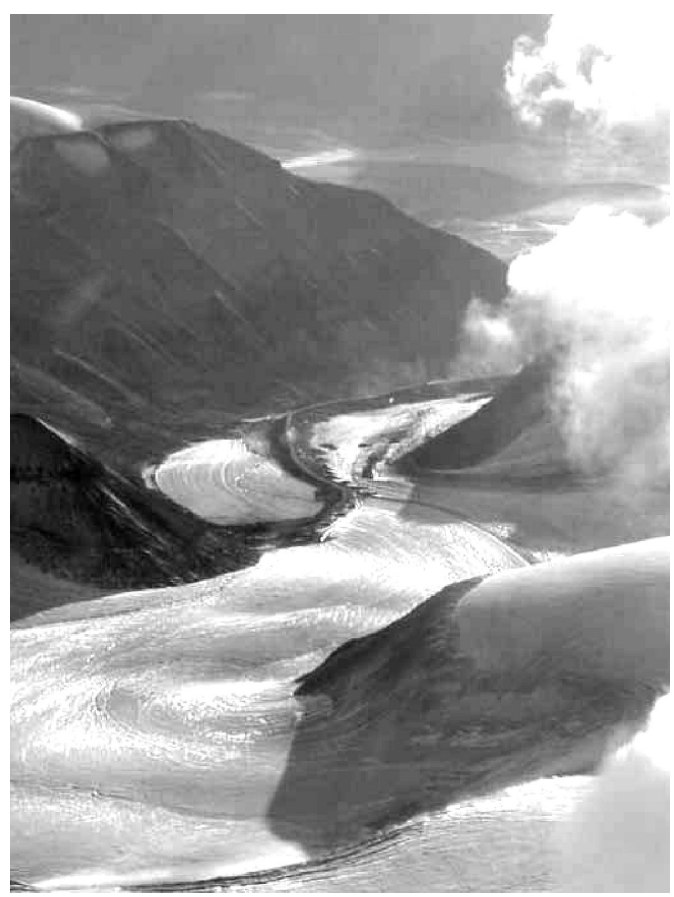

Fig. 14. Road on the Höganäs glacier from Sveagruva to the new mine, utilizing a mid-moraine as foundation for the road embankment.

tember 2001. Figure 15 shows the area covered during the DGPS investigations. It was observed that the gravel surface on the road surface insulates the underlying ice and reduces melting sig- nificantly. While the average vertical reduction in ice thickness of the glacial surface was approximately $1.5 \mathrm{~m}$ from June to September, the average vertical settlement of the gravel surface was close to zero, meaning that glacier ice ablation virtually has ceased below the road. This effect causes increased steepness of the "embankment" slope and an increase-1-2 m per year-in the height difference between the road surface and adjacent ice surface. Slope failures caused by toe instability have occurred regularly and the maintenance cost of the road is very high.

Saline permafrost is common along the coasts of Svalbard and represents an interesting engineering challenge. Biggar (1991: 92-93) reports that "the pile load carrying capacities are reduced by at least $50 \%$ at salinities as low as $5 \mathrm{ppt}$, by $60 \%$ to $75 \%$ at $10 \mathrm{ppt}$ and by as much as $90 \%$ at 15 ppt". In addition, saline pore water decreases the freezing point of the soil pore water and increases the unfrozen water content for a given temperature. The presence of saline permafrost has, therefore, been taken into consideration in geotechnical soil investigations and design of foundations on permafrost in Svalbard (Instanes \& Instanes 1999).

The bearing capacity of piles in saline permafrost is influenced by the following two effects: the adfreeze strength between the frozen soil and the pile surface is reduced due to the presence of saline pore water; piles in saline permafrost will experience larger deformations than piles in nonsaline permafrost in the design life of the piles. 


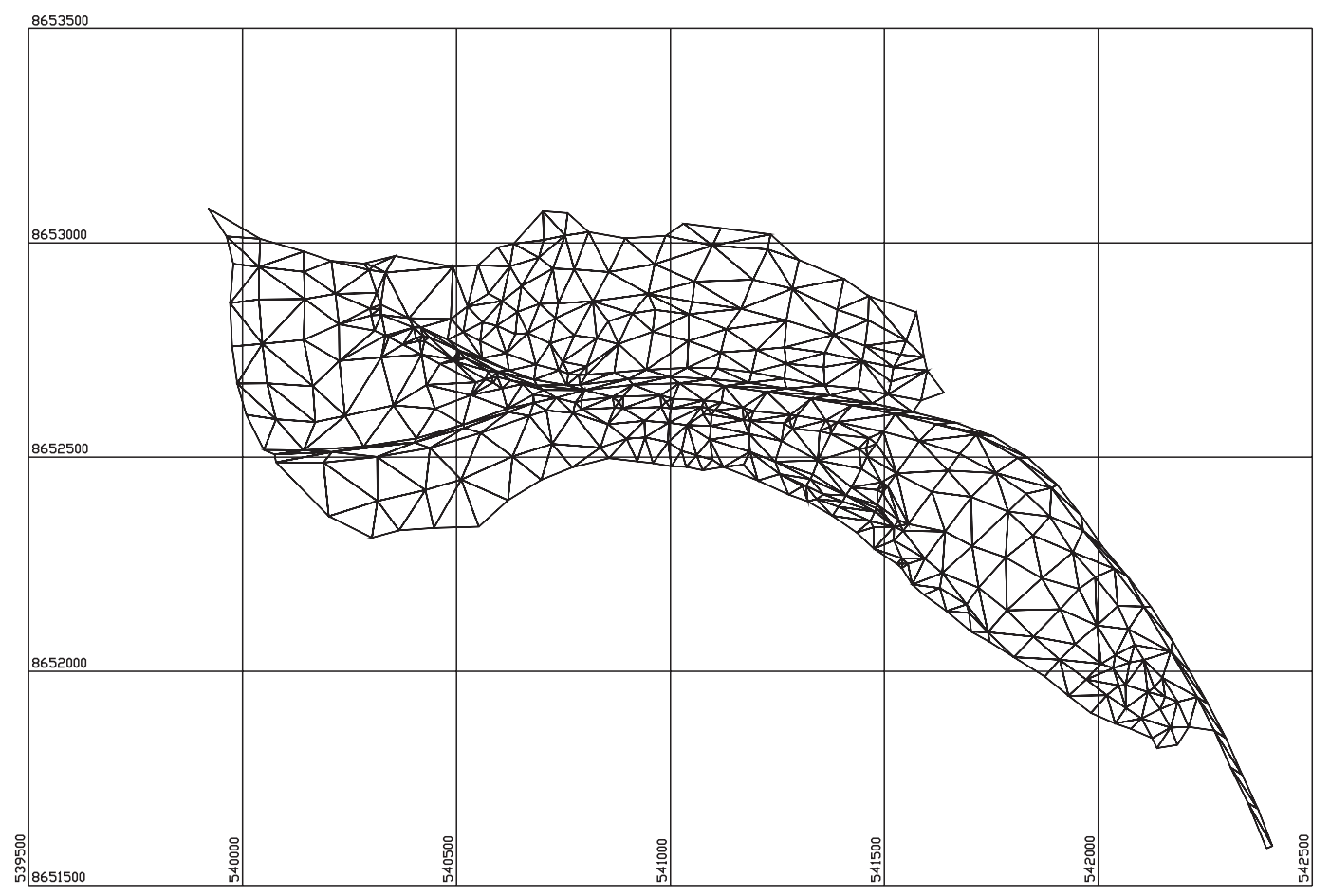

Fig. 15. Surface elevation of the road embankment on the Höganäs glacier and the adjacent glacier as measured by differential global position system (DGPS) in June and September 2001.

Environmental issues, especially the effect of hydrocarbon pollution on the physical and mechanical properties of permafrost have been subject of increased research in Svalbard during the last couple of years.

\section{Conclusions}

In contrast to many other regions with extensive permafrost, e.g. Siberia and northern Alaska, much of the present permafrost at low altitudes at least in central Svalbard is presumably of young (i.e. Late Holocene) age. It probably thawed, at least in the major valleys, during the recurrent Quaternary glaciations. High altitude permafrost in Svalbard may represent an exception to this and may be of some antiquity. In Svalbard, topography introduces local and large variations in ground temperature regime and permafrost thickness. This is due to variations in slope, aspect, altitude, topographic shading and redistribution of the winter snow cover by wind. As such, permafrost in Svalbard is highly prone to temper- ature and thickness changes when compared to permafrost in the northern lowlands of Siberia, Canada and Alaska.

Svalbard is a relatively small land area located near both the northernmost branches of the North Atlantic Current and the southern limit of polar pack ice. Even small variations in these important phenomena induce significant effects on the local Svalbard climate and permafrost that are not known from more continental permafrost regions.

From an engineering point of view, any future warming of permafrost may cause increases in creep rates of existing foundations such as piles and footings, increased creep of embankment foundations and eventual loss of adfreeze bond support for pilings. Increases in annual thaw (active layer) will cause increased thaw settlements during seasonal thawing, increased frostheave forces on pilings and increased total and differential frost heaving during winter. It has proven possible to construct roads on glaciers in permafrost areas, provided an artificial road embankment with a minimum thickness corre- 
sponding to the local active layer thickness for identical material is established. However, this solution leads over time to increasing altitude difference between the road and the adjoining glacier surface, and ultimately, to problems of slope failure.

Acknowledgements.-Careful critical reviews of the manuscript by Hugh French (University of Ottawa) and two anonymous reviewers are highly appreciated.

\section{References}

Ahlmann, H. W. 1953: Glacier variations and climatic fluctuations. Bowman Memorial Lectures, Ser. 3. New York: American Geographical Society.

Åkerman, H. J. 1980: Studies on periglacial geomorphology in west Spitsbergen. Medd. Lund Univ. Geogr. Inst. Avhandl.

Åkerman, H. J. 1982: Observations of palsas within the continuous permafrost zone in eastern Siberia and in Svalbard. Geogr. Tidsskr. 82, 45-51.

Åkerman, H. J. 1984: Notes on talus morphology and processes in Spitsbergen. Geogr. Ann. 66A, 267-284.

Åkerman, H. J. 1987: Periglacial forms of Svalbard-a review. In J. Boardman, J. (ed.): Periglacial processes and landforms in Britain and Ireland. Pp. 9-25. Cambridge: Cambridge University Press.

Andersland, O. B. \& Ladanyi, B. 1994: An introduction to frozen ground engineering. In O. B. Andersland \& B. Ladanyi (eds.): An introduction to frozen ground engineering. New York: Chapman \& Hall.

Andersson, T., Forman, S., Ingólfsson, Ó. \& Manley, W. 1999: Late Quaternary environmental history of central Prins Karls Forland, Svalbard. Boreas 28, 292-307.

André, M.-F. 1990: Geomorphological impact of spring avalanches in northwest Spitsbergen $\left(79^{\circ} \mathrm{N}\right)$. Permafrost Periglacial Process. 1, 97-110.

André, M.-F. 1994: Rock glaciers in Svalbard: tentative dating and inferred long-termed velocities. Geogr. Ann $76 A, 235-245$.

André, M.-F. 1997: Holocene rockwall retreat in Svalbard: a triple-rate evolution. Earth Surf. Process. Landforms 22, 423-440.

Anisimov, O. A., Velichko, A. A., Demchenko, P. F., Eliseev, A. V., Mokhov, I. I. \& Nechaev, V. P. 2002: Effect of climate change on permafrost in the past, present, and future. $I z v$. Atmos. Ocean. Phys. 38, S25-S39.

Bakkehøi S. 1982: Datainnsamlinga på permafroststasjonen i Svea, Svalbard. (Data collection from the permafrost station in Svea, Svalbard.) Frost i Jord 24, 3-8.

Bakkehøi, S. \& Bandis, C. 1987: A preliminary analysis of climatic data from the permafrost station at Svea, Spitsbergen. Frost Action in Soils 26, 27-32.

Bakkehøi, S. \& Bandis, C. 1988: Meteorological conditions' influence on the permafrost ground in Sveagruva, Spitsbergen. Norw. Geotech. Inst. Publ. 176, 39-43. Oslo: Norwegian Geotechnical Institute.
Ballantyne, C. K. 1978: The hydrological significance of nivation features in permafrost areas. Geogr. Ann. 60A, 51-54.

Barsch, D. 1996: Rockglaciers. Indicators for the present and former geoecology in high mountain environments. Berlin: Springer.

Berthling, I., Etzelmüller, B., Eiken, T. \& Sollid, J. L. 1998: Rock glaciers on Prins Karls Forland, Svalbard. I: internal structure, flow velocity and morphology. Permafrost Periglacial Process. 9, 135-145.

Berthling, I., Etzelmüller, B., Isaksen, K. \& Sollid, J. L. 2000: Rock glaciers on Prins Karls Forland. II: GPR soundings and the development of internal structures. Permafrost Periglacial Process. 11, 157-169.

Biggar, K. W. 1991: Adfreeze and grouted piles in saline permafrost. PhD thesis, Dept. of Civil Engineering, University of Alberta, Canada.

Björck, S., Muscheler, R., Kromer, B., Andersen, C. S., Heinemeier, J., Johnsen, S. J., Conley, D., Koç, N., Spurk, M. \& Veski, S. 2001: High-resolution analyses of an early Holocene climate event may imply decreased solar forcing as an important climate trigger. Geology 29, 1107-1110.

Bond, G., Kromer, B., Beer, J., Muscheier, R., Evans, M. N., Showers, W., Hoffmann, S., Lotti-Bond, R., Hajdas, I. \& Bonani, G. 2001: Persistent solar influence on North Atlantic climate during the Holocene. Science 294, 2130-2136.

Booij, M., Leijnse, A., Haldorsen, S., Heim, M. \& Rueslåtten, H. 1998: Subpermafrost groundvater modelling in NyÅlesund. Nord. Hydrol. 29, 385-396.

Boulton, G. S., van der Meer, J. J. M., Beets, D. J., Hart, J. K. \& Ruegg, G. H. J. 1999: The sedimentary and structural evolution of a recent push moraine complex: Holmstrombreen, Spitsbergen. Quat. Sci. Rev. 18, 339-371.

Brown, J., Hinkel, K. M. \& Nelson, F. E. 2000: The circumpolar active layer monitoring (CALM) program: research designs and initial results. Polar Geogr. 24, 163-258.

Caline, F. 2000: Modelling permafrost temperature response to variations in meteorological data. Master's thesis, Université de Marne-la-Vallée, École Nationale des Sciences Géographiques, École Nationale des Télécommunications, Marne-la-Vallée, France.

Chandler, R. J. 1973: The inclination of talus, Arctic talus terraces and other slopes composed of granular materials. $J$. Geology 81, 1-14.

Christiansen, H. C. 2003: Ice wedges in Adventdalen. In J. L. Sollid \& H. H. Christiansen (eds.): Permafrost and periglacial features and glaciers in Svalbard. Excursion guide. VIII. International Conference on Permafrost. Rapp.ser. I Naturgeogr. 14, 112-116. Dept. of Physical Geography, University of Oslo.

Christiansen, H. H., Åkerman, J. H. \& Repelewska-Pekalowa, J. 2003: Active-layer dynamics in Greenland, Svalbard and Sweden. Extended abstract for the 8th International Permafrost Conference, Zurich, July.

Cooper, R. J., Wadham, J. L., Tranter, M., Hodgkins, R. \& Peters, N. E. 2002: Groundwater hydrochemistry in the active layer of the proglacial zone, Finsterwalderbreen, Svalbard. J. Hydrol. 269, 208-223.

Dansgaard, W. \& Tauber, H. 1969: Glacier oxygen-18 content and Pleistocene ocean temperatures. Science 166 , 499-502.

Davis, J. L., Heginbottom, J. A., Annan, A. P., Daniels, R. S., Berdal, B. P., Bergan, T., Duncan, K. E., Lewin, P. K., Oxford, J. S., Roberts, N., Skehel, J. J. \& Smith, C. R. 2000: Ground penetrating radar surveys to locate 1918 Spanish Flu victims in permafrost. J. Forensic Sci. 45, 68-76. 
Dickson, R. R., Osborn, T. J., Hurrell, J. W., Meincke, J., Blindheim, J., Adlandsvik, B., Vinje, T., Alekseev, G., Maslowski, W. \& Cattle, H. 2000: The Arctic Ocean response to the North Atlantic Oscillation. J. Clim. 15, 2671-2696.

Dzierzek, J. \& Nitychoruk, J. 1987: Types of rock glaciers in northwestern Wedel Jarlsberg Land, Spitsbergen. Pol. Polar Res. 8, 231-241.

Ekholm, N. 1890: Observations météorologiques. (Meteorological observations.) In: Observations faites au Cap Thordsen, Spitzberg, par l'Expédition suédoise publiées par l'Académie Roy. des Sciences de Suède. (Observations on Kapp Thordsen, Spitsbergen, during the Swedish Expedition, published by the Royal Swedish Academy of Scienc es.) Vol. 1. Stockholm.

Elton, C. S. 1922: Geological notes from the Oxford expedition to Spitsbergen. Geogr. J. 60, 424-426.

Elton, C. S. The nature and origin of soil polygons in Spitsbergen. Quart. J. Geol. Soc. Lond. 83, 163-194.

Esch, D. C. \& Osterkamp, T. E. 1990: Cold regions engineering: climate warming concerns for Alaska. J. Cold Reg. Eng. 4, 6-14.

Etzelmüller, B. 2000: Quantification of thermo-erosion in pro-glacial areas-examples from Svalbard. Z. Geomorphol. 44, 343-361.

Etzelmüller, B. \& Sollid, J. L. 1991: The role of weathering and pedological processes for the development of sorted circles on Kvadehuksletta, Svalbard - a short report. Polar Res. 9, 181-191.

Etzelmüller, B., Hagen, J. O., Vatne, G., Ødegård, R. \& Sollid, J. L. 1996: Glacier debris accumulation and sediment deformation influenced by permafrost: examples from Svalbard. Ann. Glaciol. 22, 53-62.

Etzelmüller, B., Ødegård, R. S., Vatne, G., Mysterud, R. S., Tonning, T. \& Sollid, J. L. 2000: Glacier characteristic and sediment transfer systems of Longyearbreen and Larsbreen, western Spitsbergen. Nor. Geogr. Tidsskr. 54, 157-168.

Førland, E. J., Hanssen-Bauer, I. \& Nordli, P. Ø. 1997: Climate statistics \& longterm series of temperature and precipitation at Svalbard and Jan Mayen. Klima 21/97. Oslo: Norwegian Meteorological Institute.

Frakes, L. A., Francis, E. \& Syktus, J. I., 1992: Climate modes of the Phanerozoic: the history of the Earth's climate ove the past 600 million years. Cambridge: Cambridge University Press.

French, H. M. 1996: The periglacial environment. 2nd edition. Harlow, UK: Longman.

Friis-Christensen, E. \& Lassen, K., 1991: Length of the sola cycle: an indicator of solar activity closely associated with climate. Science 254, 698-700.

Giorgi, F. 2002: Variability and trends of sub-continental scale surface climate in the twentieth century. Part I: observations. Climate Dyn. 18, 675-691.

Glasser, N. F. \& Hambrey, M. J. 2001: Styles of sedimentation beneath Svalbard valley glaciers under changing dynamic and thermal regimes. J. Geol. Soc. Lond. 158, 697-707.

Goering, D. J. \& Kumar, P. 1996: Winter-time convection in open-graded embankments. Cold Reg. Sci. Technol. $24,57-74$

Gregersen, O. 1980: Permafrost engineering research on Spitsbergen. Frost $i$ Jord 21, 3-6.

Gregersen, O. 1988: Foundation engineering research in Svalbard. In A. Orheim \& J. L. Sollid (eds.): 5th International Conference on Permafrost. Excursion guide. Rapp.ser. Naturgeogr. 8, 26-35. Dept. of Physical Geography, Uni- versity of Oslo.

Gregersen, O. \& Eidsmoen, T. 1988: Permafrost conditions in the shore area at Svalbard. 5th. International Conference on Permafrost, Norway, August 2.-5., 1988. Nor. Geotech. Inst. Publ. 174. Oslo: Norwegian Geotechnical Institute.

Gripp, K. 1926: Über frost und strukturboden auf Spitsbergen. (Frost phenomena and patterned ground on Spitsbergen.) Z. Ges. Erdkd., 351-354.

Haeberli, W. 1985: Creep of mountain permafrost: internal structure and flow of Alpine rock glaciers. Mitt. Vers.anst. Wasserbau Hydrol. Glaziol. 77. Zurich.

Hagen, J. O. \& Lefauconnier, B. 1995: Reconstructed runoff from the High Arctic basin Bayelva based on mass-balance measurements. Nord.Hydrol. 26, 285-296.

Hagen, J. O. \& Liestøl, O. 1990: Long-term glacier massbalance investigations in Svalbard, 1950-88. Ann. Glaciol. 14, 102-106.

Hagen, J.O., Melvold, K., Pinglot, F. \& Dowdeswell, J. 2003. On the net mass balance of the glaciers and ice caps in Svalbard, Norwegian Arctic. Arct. Antarct. Alp. Res. 35, 264-270.

Haldorsen, S. \& Heim, M. 1999: An Arctic groundwater system and its dependence upon climate change: an example from Svalbard. Permafrost Periglacial Process. 10, 137-149.

Haldorsen, S., Heim, M. \& Lauritzen, S.-E. 1996: Subpermafrost groundwater, western Svalbard. Nord. Hydrol. 27, 57-68.

Hallet, B., Anderson, S. P., Stubs, C. V. \& Gregory, E. C. 1988: Surface soil displacements in sorted circles, western Spitsbergen. In K. Senneset (ed.): Proceedings of the 5th International Conference on Permafrost. Vol. 1. Pp. 770775. Trondheim: Tapir Publishers.

Hallet, B. \& Prestrud, S. 1986: Dynamics of periglacial sorted circles in western Spitsbergen. Quat. Res. 26, 81-99.

Hambrey, M. 1984: Sedimentary processes and buried ice phenomena in the pro-glacial areas of Spitsbergen glaciers. J. Glaciol. 30, 116-119.

Hamilton, G. S. \& Dowdeswell, J. A. 1996: Controls on glacier surging in Svalbard. J. Glaciol. 42, 157-168.

Harris, S. 2002:. Global heat budget, plate tectonics and climate change. Geogr. Ann. 84A, 1-9.

Hoelzle, M. 1993: DC resistivity soundings 1992 in north western Svalbard. Arbeitsheft 13. Zurich: Versuchsanstalt für Wasserbau, Hydrologie und Glaziologie, Swiss Federal Institute of Technology.

Holmsen, G. 1913: Spitsbergens jordbundsis og de bidrag dens undersøkelse har kunnet gi til forstaaelsen av de $i$ arktiske land optrcedende varige isleier i jorden. (Ground ice in Spitsbergen and contributions toward the understanding of perennial ground ice found in Arctic environments.) Det Norske Geografiske Selskaps Arbok 1912-1913, $B X X I V$

Houghton, J. T., Ding, Y., Griggs, D. J., Noguer, M., van der Linden, P. J., Dai, X., Maskell, K. \& Johnson, C. A. (eds.) 2001: Climate change 2001: the scientific basis. Contribution of Working Group I to the third assessment report of the Intergovernmental Panel on Climate Change. Cambridge: Cambridge University Press.

Humlum, O. 1981: Rock glaciers in northern Spitsbergen: a discussion. J. Geol. 90, 214-218.

Humlum, O. 1998: Active layer thermal regime 1991-1996 at Qeqertarsuaq, Disko Island, central west Greenland. Arct. Alp. Res. 30, 295-305.

Humlum, O. 1999: The climatic significance of rock glaciers. 
Permafrost Periglacial Process. 9, 375-395.

Humlum, O. 2000: The geomorphic significance of rock glaciers: estimates of rock glacier debris volumes and headwall recession rates in W Greenland. Geomorphology 35, $41-67$.

Humlum, O. 2002: Modelling late 20th century precipitation in Nordenskiöld Land, central Spitsbergen, Svalbard, by geomorphic means. Nor. Geogr. J. 56, 96-103.

Humlum, O. 2003: Permafrost in Svalbard. In J. L. Sollid \& H. H. Christiansen (eds.): Permafrost and periglacial fetures and glaciers in Svalbard. Excursion guide. VIII. International Conference on Permafrost. Rapp.ser. I Naturgeogr. 14, 15-21. Dept. of Physical Geography, University of Oslo.

Huxley, J. S. \& Odell, N. E. 1924: Notes on surface markings in Spitsbergen. Geogr. J. 63, 207-229.

Imbrie, J., Berger, A., Boyle, E.A. \& Clemens, S. C. 1993: On the structure and origin of major glaciation cycles 2 . The 100,000 year cycle. Palaeoceanography 8, 699-735.

Imbrie, J., Hays, L. D., Martinson, D. G., McIntyre, A., Mix, A. C., Morley, J. J., Pisias, N. G., Prell, W. L. \& Shackleton, N. J. 1984: The orbital theory of Pleistocene climate: support from a revised chronology of the marine ${ }^{18} \mathrm{O}$ record. In A. Berger et al. (eds.): Milankovitch and climate. Understanding the response to astronomical forcing. NATO Sci. Ser. C 176. Pp. 269-305. Dordrecht, The Netherlands: Kluwer Academic Publishing.

Imbrie, J. \& Imbrie, K. P. 1979: Ice ages: solving the mystery. London: Macmillan Press.

Instanes, A. 2001: Arctic climate impact assessment-impact on Arctic infrastructure. (Abstract.) In: Report from the Arctic Climate Impact Assessment Modeling and Scenarios Workshop, Stockholm, Sweden, 29-31 January, 2001. P. 8. Fairbanks: ACIA Secretariat.

Instanes, A. 2003: Climate change and possible impact on Arctic infrastructure. In M. Phillips et al. (eds.): Proceedings 8th International Permafrost Conference, Zürich, Switzerland. Vol. 1. Pp. 461-466. Lisse, The Netherlands: Balkema Publishers.

Instanes, A. \& Instanes, D. 1999: Pile design in saline permafrost at Longyearbyen. In J. E. Zufelt (ed.): Proceedings of the Tenth International Conference on Cold Regions Engineering, "Putting research into practive". Pp. 222-231. Reston, VA: American Society of Civil Engineers.

Instanes, B. 1988: Foundation practice in Sveagruva and Longyearbyen. In A. Orheim \& J. L.Sollid (eds.): 5th International Conference on Permafrost. Excursion guide. Rapp.ser. Naturgeogr. 8, 36-47. Dept. of Physical Geography, University of Oslo.

Instanes, B. 2000: Permafrost engineering on Svalbard. In K. Senneset (ed.): Proceedings of the International Workshop on Permafrost Engineering. Pp. 3-23. Trondheim: Tapir Publishers.

Instanes, D. \& Instanes, A. 1998: Frozen ground temperature profiles at Svalbard Airport, Spitsbergen. In: Proceedings of the International Conference of Natural and Artificial Cooling Cold Regions Engineering. Pp. 229-237. Paris: International Institute of Refrigeration.

Isaksen, K. 2001: Past and present ground thermal regime, distribution and creep of permafrost-case studies in Svalbard, Sweden and Norway. Thesis, Faculty of Mathematics and Natural Sciences, University of Oslo.

Isaksen, K., Ødegård, R.S., Eiken, T. \& Sollid, J. L. 2000: Composition, flow and development of two tongue-shaped rock glaciers in the permafrost of Svalbard. Permafrost
Periglacial Process. 11, 241-257.

Isaksen, K., Holmlund, P., Sollid, J. L. \& Harris, C. 2001: Three deep alpine-permafrost boreholes in Svalbard and Scandinavia. Permafrost Periglacial Process. 12, 13-25.

Isaksen, K., Humlum, O. \& Sollid, J. L. 2003: The Janssonhaugen PACE borehole, Svalbard. In J. L. Sollid \& H. H. Christiansen (eds.): Permafrost and periglacial fetures and glaciers in Svalbard. Excursion guide. VIII. International Conference on Permafrost. Rapp.ser. I Naturgeogr. 14, 2128. Dept. of Physical Geography, University of Oslo.

Isaksen, K., Humlum, O., Sollid, J. L. \& Harris, C. 2003: Permafrost temperature monitoring, Janssonhaugen, Svalbard: a five-years series. Abstract. EGS-AUG-EGU Joint Assembly, Nice. EAEO3-A-10767 Geophys. Res. Abstr. 5.

Isaksen, K, Vonder Mühll, D., Gubler, H., Kohl T. \& Sollid J. L. 2000: Ground surface temperature reconstruction based on data from a deep borehole in permafrost at Janssonhaugen, Svalbard. Ann. Glaciol. 31, 287-294.

Jahn, A. 1960: Some remarks on evolution of slopes on Spitsbergen. Z. Geomorphol. Suppl.bd. 1, 49-58.

Jahn, A. 1965: Origin and development of patterned ground in Spitsbergen. In: Permafrost International Conference on Proceedings, Lafayette, Indiana, 11-15 November 1963. NAS-NRC Publ. 1287. Pp. 140-145. Washington, D. C.: National Academy of Sciences/National Research Council.

Jahn, A. 1967: Some features of mass movement on Spitsbergen slopes. Geogr. Ann. 49A, 213-224.

Jahn, A. 1975: Problems of the periglacial zone. Warsaw: Polish Scientific Publishers.

Jahn, A. 1976: Contemporaneous geomorphological processes in Longyeardalen, Westspitsbergen (Svalbard). Beuletun Peryglacjalny 26, 254-268.

Jansen, E. \& Sjøholm, J. 1991: Reconstruction of glaciation over the past 6 Ma based on Norwegian Sea records. Nature $349,600-603$.

Japsen, P. \& Chalmers, J. A. 2000: Neogene uplift and tectonics around the North Atlantic: overview. Glob. Planet. Change 24, 165-173.

Jeppesen, J. W. 2001: Palceoklimatiske indicatorer for central Spitsbergen, Svalbard. Eksemplificeret ved studier af iskiler og deres vartssedimenter. (Ice wedges and host sediments as palaeoclimatic indicators in central Spitsbergen, Svalbard.) MSc thesis, The University Courses on Svalbard.

Kääb, A., Isaksen, K., Eiken, T. \& Farbrot, H. 2002: Geometry and dynamics of two lobe-shaped rock glaciers in the permafrost of Svalbard. Nor. J. Geogr. 56, 152-160.

Kessler, M. A. \& Werner, B. T. 2003: Self-organization of sorted patterned ground. Science 299, 380-383.

Khrustalev, L. N. 2000: Allowance for climate change in designing foundations on permafrost grounds. In K. Senneset (ed.): Proceedings of the International Workshop on Permafrost Engineering. Pp. 25-36. Trondheim: Tapir Publishers.

Khrustalev, L. N. 2001: Problems of permafrost engineering as related to global climate warming. In R. Paepe \& V. Melnikov (eds.): Permafrost response on economic development, environmental security and natural resources. Pp. 407-423. Dordrecht, The Netherlands: Kluwer Academic Publishers.

Killingtveit, Å., Petterson, L.E. \& Sand, K. 1996: Killingtveit, Å., Petterson, L.-E. \& Sand, K. 1994: Water balance studies at Spitsbergen, Svalbard. In K. Sand \& $\AA$. Killingtveit (eds.): Proceedings of the 10th Internation- 
al Northern Research Basins Symposium and Workshop Spitsbergen, Norway. SINTEF Rep. 22 A96415. Pp. 77-94. Trondheim: Norwegian Institute of Technology.

Korsgaard, S. 2002: Geomorfologisk analyse af Ugledalen blokgletscher. Det Centrale Spitsbergen, Svalbard. (Geomorphic analysis of Ugledalen rock glacier, central Spitsbergen, Svalbard.) MSc thesis, The University Courses on Svalbard.

Kristiansen, K. J. \& Sollid, J. L. 1986: Svalbard—glacialgeology and geomorphology, 1:1000 000, map 2.3.5. National Atlas of Norway. Hønefoss: Statens Kartverk.

Kukla, G. 1987: Loess stratigraphy in central China. Quat Sci. Rev. 6, 191-219.

Kulling, O. 1937: Über präkarbonische Klimazeugnisse aus Svalbard (Bäreninsel, Spitsbergen und umliegenden Inselen). (Pre-Carboniferous climatic indicators from Svalbard [Bjørnøya, Spitsbergen and surrounding islands].) In International Geological Congress, XVII session, abstract papers. P. 211. Leningrad: International Geological Congress.

Lachenbruch, A. 1962: Mechanics of thermal contraction cracks and ice-wedge polygons in permafrost. Geol. Soc. Am. Spec. Pap. 70.

Ladanyi, B. 1995: Civil engineering concerns of climate change in the Arctic. Trans. R. Soc. Can. Ser. VI, Vol. VI $7-20$

Ladanyi, B. 1996: A strength sensitivity index for assessing climate warming effects on permafrost. In R. F. Carlsson (ed.): Proceedings of the 8th International Conference on Cold Regions Engineering, "The cold regions infrastructure: an international imperative for the 21st century". Pp. 35-45. New York: ASCE Press.

Ladanyi, B., Lunne, T., Vergobbi, P. \& Lhuillier, B. 1997: Predicting creep settlements for foundations in permafrost based on the results of in-situ tests at Svea, Svalbard. Nor. Geotech. Inst. Publ. 201. Oslo: Norwegian Geotechnical Institute.

Ladanyi, B., Smith, M. W. \& Riseborough, D. W. 1996: Assessing the climate warming effects on permafrost engineering. In: 49th Canadian Geotechnical Conference of the Canadian Geotechnical Society. Pp. 295-302. Alliston, Ontario: Canadian Geotechnical Society.

Lamb, H. H. 1977: Climate: present, past and future. Vol. 2. Climatic history and the future. London: Methuen.

Landvik, J. Y., Brook, E. J., Gualteri, L., Raisbeck, G., Salvigsen, O. \& Yiou, F. 2003: Northwest Svalbard during the last glaciation: ice-free areas existed. Geology 31, 905-908.

Landvik, J. Y., Mangerud, J. \& Salvigsen, O. 1988: Glacial history and permafrost in the Svalbard area. In K. Senneset (ed.): Proceedings of the 5th International Conference on Permafrost. Vol. 1. Pp. 194-198. Trondheim: Tapir Publishers.

Landvik, J. Y., Bondevik, S., Elverhøi. A., Fjeldskaar, W., Mangerud. J., Siegert, M. J., Salvigsen, O., Svendsen, J.I. \& Vorren, T. O. 1998: The last glacial maximum of Svalbard and the Barents Sea area: ice sheet extent and configuration. Quat. Sci. Rev. 17, 43-76.

Larsson, S. 1982: Geomorphological effects on the slopes of Longyear Valley, Spitsbergen, after a heavy rainstorm in July 1972. Geogr. Ann. 64A, 105-125.

Lauritzen, S.-E. 1991: Groundwater in cold climates: interaction between glacier and karst aquifers. In Y. Gjessing et al. (eds): Arctic hydrology, present and future tasks. Rep. 23. Pp. 139-146. Oslo: Norwegian National Committee for Hydrology.
Lauritzen, S.-E. \& Bottrell, S. 1994: Microbiological activity in thermoglacial karst springs, south Spitsbergen. Geomicrobiol. J. 12, 161-173.

Leffingwell, E. K. 1915: Ground-ice wedges, the dominant form of ground-ice on the north coast of Alaska. J. Geol. 23, 635-654.

Lehmann, R. 1993: The significance of permafrost in the formation and appearance of push moraines, examples of the Canadian Arctic and Spitsbergen. In K. Senneset (ed.): Proceedings of the 5th International Conference on Permafrost. Vol. 1. 374-379. Tronheim: Tapir Publishers.

Liestøl, O. 1962: Talus terraces in Arctic regions. Nor. Polarinst. Arb. 1961, 102-105.

Liestøl, O., 1976: Pingos, springs, and permafrost in Spitsbergen. Nor. Polarinst. Arb. 1975, 7-29.

Liestøl O. 1980: Permafrost conditions in Spitsbergen. Frost i Jord 21, 23-28.

Liestøl O. 1986: Permafrost på Svalbard og på fastlandet. Klimatiske forutsetninger, utbredelse og tykkelse. (Permafrost in Svalbard and in Norway. Climatic background, distribution and thickness.) In A. M. Hletzen et al. (eds.): Fjellspregningsteknikk, bergmekanikk og geoteknikk. (Blasting technique in bedrock, rock mechanics and geotechniques.) Pp. 20.1-20.8. Trondheim: Tapir.

Liestøl, O. 1996: Open-system pingos in Spitsbergen. Nor. Geogr. Tidsskr. 50, 81-84.

Lindner, L. \& Marks, L. 1985: Types of debris-slope accumulations and rock glaciers in south Spitsbergen. Boreas $14,139-153$.

Lunardini, V. J. 2001: Climate warming and permafrost. In R. Paepe \& V. Melnikov (eds.): Permafrost response on economic development, environmental security and natural resources. Pp. 341-346. Dordrecht, The Netherlands: Kluwer Academic Publishers.

Lunne, T. \& Eidsmoen, T. 1988: Long term plate load tests on marine clay in Svea, Svalbard. Norw. Geotech. Inst. Publ. 174. Oslo: Norwegial Geotechnical Institute.

Matsuoka, N. 1999: Monitoring of thermal contraction at an ice-wedge site, central Spitsbergen. Polar Geosci. 12, 258-271.

Mackay, J. R. 1972: The world of underground ice. Ann Assoc. Am. Geogr. 62, 1-22.

Mercier, D. 2002: Paraglacial dynamics of the slopes of Svalbard. Z. Geomorphol. 46, 203-222.

Milankovitch, M. 1930: Mathematische klimalehre und astronomische theorie der klimaschwankungen. Handbuch der klimalogie. (Mathematic climatology and astronomical theory for climate changes. Handbook of climatology.) Vol. 1. Berlin: Borntrager.

Milankovitch, M. 1941: Kanon der erdbestrahlungen und seine anwendung auf das eiszeitenproblem. (Canon of insolation and the ice age problem.) Belgrade.

Miller, K. G., Wright, J. D. \& Fairbanks, R. G. 1991: Unlocking the ice house: Oligocene-Miocene oxygen isotopes, eustacy and margin erosion. J. Geophys. Res. 96(B4), 6829-6848.

Mjureke, D. 2001: Impacts of climate change on Arctic infrastructure: case study on Svalbard Airport. MSc thesis, The University Courses on Svalbard.

Müller, F. 1959: Beobachtung über pingos. (Observations on pingos.) Medd. Grønl. 153, 1-127.

Murray, T., Stuart, G. W., Miller, P. J., Woodward, J., Smith, A. M., Porter, P. R. \& Jiskoot, H. 2000: Glacier surge propagation by thermal evolution at the bed. J. Geophys. Res. 105(B6), 13491-13507. 
Nelson, F. E., Anisimov, O. A. \& Shiklomanov, N. I. 2001: Subsidence risk from thawing permafrost - the threat to man-made structures across regions in the far north can be monitored. Nature 410, 889-890.

Nelson, F. E., Anisimov, O. A. \& Shiklomanov, N. I. 2002: Climate change and hazard zonation in the circum-Arctic permafrost regions. Nat. Hazards 26, 203-225.

Nixon, J. F. 1990a: Effect of climate change on pile creep in permafrost. J. Cold Reg. Eng. 4, 67-73.

Nixon, J. F. 1990b: Seasonal and climate warming effects on pile creep in permafrost. In: Proceedings of the 5th Canadian Permafrost Conference, Quebec, Canada, 1990. Pp. 335-340. Ste.-Fuy, Canada: Centre d'étude nordiques, University of Laval.

Ødegård, R. S., Etzelmüller, B., Vatne, G. \& Sollid, J .L. 1995: Near-surface spring temperatures in an Arctic coastal rock cliff: possible implications for rock breakdown. In O. Slaymaker (ed.): Steepland geomorphology. Pp. 89-102. Wiley, Chichester: Wiley.

Ødegård, R. S., Hamran, S.-E., Bø, P. H., Etzelmüller, B., Vatne, G. \& Sollid, J. L. 1992: Thermal regime of a valley glacier, Erikbreen, northern Spitsbergen, Svalbard. Polar Res. 11, 69-79.

Ødegård, R. S., Isaksen, K., Eiken, T. \& Sollid, J .L. 2003a: A conceptual model of Hiorthfjellet rock glacier. In M. Phillips et al. (eds.): Proceedings 8th International Permafrost Conference, Zürich, Switzerland. Vol. 2. Pp. 839-844. Lisse, The Netherlands: Balkema Publishers.

Ødegård, R. S., Isaksen, K., Eiken, T. \& Sollid, J .L. 2003b: Terrain analyses and surface velocity measurements of the Hiorthfjellet rock glacier, Svalbard. Permafrost Periglacial Process. 14, 1-7.

Ødegård, R. S. \& Sollid, J. L. 1993: Coastal cliff temperatures related to the potential for cryogenic weathering processes, western Spitsbergen. Polar Res. 12, 95-106.

Oht, M. 2002: Impact of meteorological factors and local conditions on active layer depth and temperature, Adventdalen area in central Spitsbergen, Svalbard. MSc thesis, University of Copenhagen and the University Courses on Svalbard.

Oht, M. 2003: Impact of meteorological factors on active layer development in central Spitsbergen. In M. Phillips et al. (eds.): Proceedings 8th International Permafrost Conference, Zürich, Switzerland. Vol. 2. Pp. 845-850. Lisse, The Netherlands: Balkema Publishers.

Orheim, A. 1988: Mining. In A. Orheim \& J. L.Sollid (eds.): 5th International Conference on Permafrost. Excursion guide. Rapp.ser. Naturgeogr. 8, 48-49. Dept. of Physical Geography, University of Oslo.

Orvin, A. K. 1941: Hvordan opstår jordbunnsis? (Genesis of ground ice?) Nor. Geogr. Tidsskr. 8, 1-16.

Orvin, A. K. 1944: Litt om kilder på Svalbard. (A note on the springs of Svalbard.) Nor. Geogr. Tidsskr. 10, 1-26.

Pang, K. D. \& Yau, K. K. 2002: Ancient observations link changes in Sun's brightness and Earth's climate. EOS Trans. Am. Geophys. Union 83, 481-490.

Péwé, T. 1979: Svalbard geology and permafrost. Natl. Sci. Found. Trip Rep. 1979.

Péwé, T. 1983: Alpine permafrost in the contiguous United States: a review. Arct. Alp. Res. 15, 145-156.

Péwé, T., Rowan, D. E. \& Péwé, R. H. 1981: Engineering geology of the Svea lowland, Spitsbergen, Svalbard. Frost $i$ Jord 23, 3-11.

Polyakov, I., Akasofu, S.-I., Bhatt, U., Colony, R., Ikeda, M., Makshtas, A., Swingley, C., Walsh, D. \& Walsh, J. 2002:
Trends and variations in Arctic climate systems. EOS Trans. Am. Geophys. Union 83, 547-548.

Polyakov, I. V., Alekseev, G. V., Bekryaev, R. V., Bhatt, U., Colony, R. L., Johnson, M. A., Karklin, V. P., Makshtas, A. P., Walsh, D. \& Yulin, A. V. 2002: Observationally based assessment of polar amplification of global warming. Geophys. Res. Lett. 29, 1878, 25-1-25-4.

Prick, A. 2003: Frost weathering and rock fall in an arctic environment, Longyearbyen, Svalbard. In M. Phillips et al. (eds.): Proceedings 8th International Permafrost Conference, Zürich, Switzerland. Vol. 2. Pp. 907-912. Lisse, The Netherlands: Balkema Publishers.

Prick, A. in press: Rock weathering in central Spitsbergen and in northern Victoria Land (Antarctica). Ann. Marie Curie Fellowships.

Putkonen, J. 1998: Soil thermal properties and heat transfer processes near Ny-Ålesund, northwestern Spitsbergen, Svalbard. Polar Res. 17, 165-179.

Rapp, A. 1960: Talus slopes and mountain walls at Tempelfjorden, Spitsbergen. Nor. Polarinst. Skr. 119.

Raymo, M. E. 1992: Global climate change: a three million year perspective. In G. J. Kukla \& E. Went (eds.): Start of a glacial. NATO ASI Ser., Ser. 1, Global Environmental Change 3, 207-223.

Repelewska-Pekalowa, J. 1988: Dynamic and permafrost active layer-Spitsbergen. In K. Senneset (ed.): Proceedings of the 5th International Conference on Permafrost. Vol. 1. Pp. 448-453. Trondheim: Tapir Publishers.

Ronnert, L. \& Landvik, J. Y. 1993: Holocene glacial advances and moraine formation at Albrechtbreen, Edgeoya, Svalbard. Polar Res. 12, 57-63.

Roth, K. \& Boike, J. 2001: Quantifying the thermal dynamics of a permafrost site near Ny-Ålesund, Svalbard. Water Resour. Res. 37, 2901-2914.

Ruddiman, W. F., Raymo, M. E. \& McIntyre, A. 1996: Matuyama 41000 -year cycles; North Atlantic Ocean and Northern Hemisphere ice sheets. Earth Planet. Sci. Lett. 80, 117-129.

Salvigsen, O. 1977: An observation of palsa-like forms in Nordaustlandet, Svalbard. Nor. Polarinst. Arb. 1975, 364-367.

Salvigsen, O. \& Elgersma, A. 1985: Kvartcergeologiske undersøkelser $i$ området Lewinodden-Kapp Starostin-Linnevannet, Ytre Isfjorden, Svalbard. (Quaternary geology in the Lewinodden-Kapp Starostin-Linnevatnet, outermost Isfjorden, Svalbard.) Thesis, University of Bergen.

Salvigsen, O., Forman, S. L. \& Miller, G. H. 1992: Thermophilous molluscs on Svalbard during the Holocene and their paleoclimatic implications. Polar Res. 11, 1-10.

Salvigsen, O., Lauritzen, Ø. \& Mangerud, J. 1983: Karst and karstification in gypsiferous beds in Mathiesondalen, central Spitsbergen, Svalbard. Polar Res. 1, 83-88.

Sandsbråten, K. 1995: Vannbalanse i et lite, arktisk nedbørsfelt. Tvillingvatn, Svalbard (Water balance in a small Arctic drainage area. Lake Tvillingvatn, Svalbard.) Rapp.ser. Hydrol. 43. University of Oslo.

Serreze, M. C. \& R. G. Barry. 1988: Synoptic activity in the Arctic Basin, 1979-85. J. Clim. 1, 1293.

Serreze, M. C., Barry, R. G., Rehder, M. C. \& Walsh, J. E.. 1995: Variability in atmospheric circulation and moisture flux over the Arctic. Philos. Trans. R. Soc. Lond. A 352, 215-225.

Serreze, M. C., Box, J. E., Barry, R. G. \& Walsh, J. E. 1993: Characteristics of Arctic synoptic activity, 1952-1989. Meteorol. Atmos. Phys. 51, 147-164.

Shaviv, N. J. \& Veizer, J. 2003: Celestial driver of Phanerozo- 
ic climate? Geol. Surv. Am. Today 13(7), 4-10.

Shapiro, I., Colony, R. \& Vinje, T. 2003. April sea ice extent in the Barents Sea, 1850-2001. Polar Res. 22, 5-10.

Snyder, J. A., Werner, A. \& Miller, G. H. 2000: Holocene cirque glacier activity in western Spitsbergen, Svalbard; sediment records from proglacial Linnévatnet. The Holocene 10, 555-563.

Solanki, S. K. 2002: Solar variability and climate change: is there a link? Astron. Geophys. 43, 5.9-5.13.

Sollid, J. L., Etzelmüller, B., Vatne, G. \& Ødegård, R. 1994 Glacial dynamics, material transfer and sedimentation of Erikbreen and Hannabreen, Liefdefjorden, northern Spitsbergen. Z. Geomorphol. Suppl.bd. 97, 123-144.

Sollid J. L, Holmlund P., Isaksen, K. \& Harris C. 2000: Deep permafrost boreholes in western Svalbard, northern Sweden and southern Norway. Nor. Geogr. Tidsskr. $54,186-191$.

Sollid, J. L. \& Sørbel. L. 1988a: Utbredelsesmønstret av løsmateriale og landformer på Svalbard-noen hovedtrekk (Distribution of sediments and landforms in Svalbard - an outline.) Norsk Geogr. Tidsskr. 42, 265-270.

Sollid, J. L. \& Sørbel, L. 1988b: Influence of temperature conditions in formation of end moraines in Fennoscandia and Svalbard. Boreas 17, 553-558.

Sollid, J .L. \& Sørbel, L. 1992: Rock glaciers in Svalbard and Norway. Permafrost Periglacial Process. 3, 215-220.

Soon, W. H., Posmentier, E. S. \& Baliunas, S. L. 1996: Inference of solar irradiance variability from terrestrial temperature changes, 1880-1993: an astrophysical application of the Sun-climate connection. Astrophys. J. 472, 891-902.

Soon, W. H., Posmentier, E. S. \& Baliunas, S. L. 2000: Climate hypersensitivity to solar forcing? Ann. Geophys. 18 583-588.

Sørbel, L. \& Tolgensbakk, J. 2002: Ice-wedge polygons and solifluction in the Adventdalen area, Spitsbergen, Svalbard. Nor. Geogr. Tidsskr. 56, 62-66.

Sørbel, L., Tolgensbakk, J., Hagen, J. O. \& Høgvard, K. 2001: Geomorphological and Quaternary geological map of Svalbard. 1:100,000. Sheet C9Q Adventdalen. Norw. Polar Inst. Temakart 31/32.

Summerfield, M. A. 1983: Silcrete as a palaeoclimatic indicator: evidence from southern Africa. Palaeogeogr. Palaeoclimatol. Palaeoecol. 41, 65-79.

Summerfield, M. A. 1991: Global geomorphology. An introduction to the study of landforms. London: Longman.

Svensmark, H. 1998: Influence of cosmic rays on Earth's climate. Phys. Rev. Lett. 81, 5027-5030.

Sverdrup, H. U. 1935: Scientific results of the NorwegianSwedish Spitsbergen Expedition in 1934. Part III. The temperature of the firn on Isachsen's Plateau and general conclusions regarding the temperature of the glaciers on west Spitsbergen. Geogr. Ann. 17, 53-88.

Svendsen, J. I. \& Mangerud, J. 1997: Holocene glacial and climatic variations on Spitsbergen, Svalbard. The Holocene 7, 45-57.

Svensson, H. 1971: Pingos i yttre delen av Adventdalen. (Pingos in outermost Adventdalen valley.) Nor. Polarinst. Arb. 1969, 168-174.

Svensson, H. 1976: Iskilar som klimaindikator. (Ice wedges as climatic indicators.) Medd. Lunds Univ. Geogr. Inst. Sven. Geogr. Arrb. 52, 46-57.

Swett, K., Hambrey, M. J. \& Johnson, D. B. 1980: Rock glacier in northern Spitsbergen. J. Geol. 88, 475-482.

Tinsley, B. A. \& Deen, G. W. 1991: Apparent tropospheric response to $\mathrm{MeV}-\mathrm{GeV}$ particle flux variations: a connection via electrofreezing of supercooled water in high-level clouds? J. Geophys. Res. 12, 22 283-22296.

Tolgensbakk, J. \& Sollid, J. L 1987: Kvadehuksletta, geomorfologi og kvartcergeologi 1:10,000. (Kvadehuksletta, geomorphology and Quaternary geology 1:10,000.) Dept. of Physical Geography, University of Oslo.

Tolgensbakk, J, Sørbel, L. \& Høgvard, K. 2001: Geomor phological and Quaternary geological map of Svalbard 1: 100,000. Sheet C9Q Adventdalen. Map. Norw. Polar Inst Temakart $31 / 32$.

Van der Wateren, D. 1992: Structural geology and sedimentology of push moraines. Dissertation, Faculteit der Ruimtelijke Wetenschappen, University of Amsterdam.

Vatne, G., Etzelmüller, B., Sollid, J. L. \& Ødegård, R.S. 1995 Hydrology of a polythermal glacier, Erikbreen, northern Spitsbergen. Nord. Hydrol. 26, 169-190.

Vonder Mühll, D. 1996: Gravimetrical investigation in the permafrost of two selected rock glaciers near $\mathrm{Ny}$-Alesund, Svalbard. Arbeitsheft 18. Zurich: Versuchsanstalt für Wasserbau, Hydrologie und Glaziologie, Swiss Federal Institute of Technology.

Washburn, A. L. 1956: Classification of patterned ground and review of suggested origins. Bull. Geol. Soc. Am. 67, $823-865$

Weertman, J. 1969: Water lubrication mechanism of glacier surges. Can. J. Earth Sci. 6, 929-939.

Werenskiold, W. 1922: Frozen earth in Spitsbergen. Geofys. Publ. 2(10), 3-10.

Yoshikawa, K. \& Harada, K. 1995: Observations on nearshore pingo growth, Adventdalen, Spitsbergen. Permafrost Periglacial Process. 6, 361-372.

Zachos, C. Z., Flower, B. P. \& Paul, H. 1997: Orbitally paced climate oscillations across the Oligocene/Miocene boundary. Nature $388,567-570$.

Zachos, J., Pagani, M., Sloan, L., Thomas, E. \& Billups, K. 2001: Trends, rhythms, and aberrations in global climate 65 Ma to present. Science 292, 686-693.

Zhang, T., Heginbottom, J. A., Barry, R. E. \& Brown, J. 2000: Further statistics on the distribution of permafrost and ground ice in the Northern Hemisphere. Polar Geogr. $24,126-131$. 